NBER WORKING PAPER SERIES

\title{
WHAT DO WE LEARN FROM STOCK PRICE REACTIONS TO CHINA'S FIRST ANNOUNCEMENT OF ANTI-CORRUPTION REFORMS?
}

\author{
Chen Lin \\ Randall Morck \\ Bernard Yeung \\ Xiaofeng Zhao \\ Working Paper 22001 \\ http://www.nber.org/papers/w22001 \\ NATIONAL BUREAU OF ECONOMIC RESEARCH \\ 1050 Massachusetts Avenue \\ Cambridge, MA 02138 \\ February 2016
}

We are grateful for comments from Sumit Agarwal, Philip H. Dybvig, Raymond Fisman, Hanming Fang, Ali Hortaçsu, Yongmiao Hong, James Levinsohn, Hongbin Li, and Yingyi Qian. We also appreciate the comments from the seminar participants at the National Bureau of Economic Research (NBER) May 2015 Chinese Economy Workshop, the ABFER 2016, the 2nd China-Europe Conference: Transparency, Economic Institutions and Governance, and The 2016 Greater China Area Finance Conference. We would like to thank researchers from The Chinese University of Hong Kong, Columbia University, Hebrew University of Jerusalem, Hong Kong Monetary Authority, National University of Singapore (NUS) Business School, Lingnan University, the University of British Columbia, University of California Los Angeles (UCLA) Anderson School of Management, the University of Chicago, the University of Maryland, and the University of Philadelphia. Randall Morck would like to thank the Bank of Canada for partial funding. The views expressed herein are those of the authors and do not necessarily reflect the views of the National Bureau of Economic Research.

NBER working papers are circulated for discussion and comment purposes. They have not been peerreviewed or been subject to the review by the NBER Board of Directors that accompanies official NBER publications.

(C) 2016 by Chen Lin, Randall Morck, Bernard Yeung, and Xiaofeng Zhao. All rights reserved. Short sections of text, not to exceed two paragraphs, may be quoted without explicit permission provided that full credit, including $\odot$ notice, is given to the source. 
What do we learn from stock price reactions to China's first announcement of anti-corruption reforms?

Chen Lin, Randall Morck, Bernard Yeung, and Xiaofeng Zhao

NBER Working Paper No. 22001

February 2016, Revised August 2020

JEL No. D70,G34,G38,P2

\section{ABSTRACT}

China's markets gained 3.86\% around December 4, 2012, when the Party announced anticorruption reforms. State-owned enterprises (SOEs) with higher past entertainment and travel costs (ETC) gained more. NonSOEs gained in more liberalized provinces, especially those with high past ETC, productivity, growth opportunities, and external financing. NonSOEs lost in the least liberalized provinces, especially those with high past ETC. These findings support investors' expect reduced official corruption to create value overall, reduce SOE waste, lower bureaucratic barriers to efficient resource allocation where markets function, and impede business in unliberalized provinces, where "getting things done" still requires investment in greasing bureaucratic gears.

Chen Lin

Faculty of Business and Economics

The University of Hong Kong

Hong Kong

chenlin1@hku.hk

Randall Morck

Faculty of Business

University of Alberta

Edmonton, AB T6G 2R6

CANADA

and NBER

randall.morck@ualberta.ca
Bernard Yeung

National University of Singapore

Mochtar Riady Building

15 Kent Ridge Drive

BIZ 1, Level 6, \#6-19

Singapore

bizyeung@nus.edu.sg

Xiaofeng Zhao

Lingnan University

8 Castle Peak Road, Tuen Mun, HK

x4zhao@ln.edu.hk 


\section{Introduction}

Curtailing official corruption is a public policy priority in China and elsewhere (World Bank, 2015). Corruption is thought to slow long-term economic growth (Krueger, 1974; Murphy et al., 1993; Shleifer and Vishny, 1993; Mauro, 1995; Fisman and Svensson, 2007; Ayyagari et al., 2014). Corrupt officials' diversion of resources into private benefits for themselves, their families, or members of their patronage networks causes allocative inefficiency within the state sector, including in state-owned enterprises (SOEs). Corrupt officials' "tolls," the artificial legal, regulatory, and licensing barriers explicitly designed to be waived in return for bribes, result in allocative inefficiency in the broader economy. Curtailing corruption can lower tolls so that firms can better respond to market forces, which can then better allocate resources to their highest-value uses.

However, curbing corruption may not boost economic growth immediately. If the institutions that support market forces are ill-developed, firms' access to business opportunities can require investment in official connections - that is, bribing officials to grease jammed bureaucratic gears to "get things done" (Fisman, 2001; Wei, 2001; McMillan and Woodruff, 2002; Li et al., 2008, Agarwal et al., 2019; Zeume, 2016). Such investments generate returns in the form of political rents, additional cash flows connected to firms that can "get things done" that unconnected firms cannot (Krueger 1974). Pervasive corruption can emerge as a second-best suboptimal equilibrium, stabilized by connected firms protecting the values of their connections and officials protecting their streams of private benefits. Although this situation can be profoundly suboptimal (Murphy et al., 1991, 1993), disturbing it necessarily reduces the values of firms' previous investments in official connections. Indeed, where markets are dysfunctional and bureaucrats allocate resources, eliminating corruption might slow economic growth by jamming bureaucratic gears.

The level of market development thus determines the economic impact of curtailing corruption. This relationship highlights the need to liberalize markets before, or in conjunction with, reducing corruption. We empirically explore how prior market liberalization affects the impact of reducing corruption using event study tests exploiting a natural experiment in China.

On December 4, 2012, China's new administration announced a comprehensive anti- 
corruption campaign, the Eight-Point Policy. This new Party Policy ordered cadres to forego conspicuous perks and other obtrusive behavior and explicitly forbade officials and state-owned enterprise (SOE) top executives, who are all Party cadres, from demanding or accepting extravagant perks. A prominent member of the State Council-directed Chinese Academy of Governance, a key institution for training senior and mid-level officials, spelled out the policy's intent: "The Politburo took the lead to change work style, it will play a critical role in fighting corruption at the root." 1

This policy was unexpected. First, although Xi Jinping had been appointed to succeed the outgoing $\mathrm{Hu}$ Jintao in the $18^{\text {th }}$ National Congress (November 8 to 14, 2012), the distribution of power across Party factions still appeared to be unsettled. The announcement of a major new Party Policy only 20 days into a new term was unprecedented. New administrations typically roll out new policies a year into their terms, in their Central Committees' Third Plenums, after the distribution of power across factions is settled and political consensus is attained. Second, the policy is unusually detailed and free of sloganeering, characteristics interpreted as evidence that the reforms were genuine. This impression was reinforced when the policy was quickly given prominence on Party websites and in re-training sessions for cadres. All this suggests investors would have considered the Eight-Point Policy a genuine anti-corruption initiative.

The validity of an event study depends on the information content of stock price movements. In these years, the information environment in China's stock markets had improved substantially relative to the 1990s. Using 1995 to 2016 data, Carpenter et al. (2020) report that "stock prices have become as informative about future profits in China as they are in the US since 2004." Many credible studies now use Chinese stock prices, particularly event studies (e.g., Calomiris et al., 2010; Fisman and Wang 2015; Jia et al., 2017; Liu et al., 2017; Giannetti et al., 2015). Our observation window also precedes the high market-volatility episodes of 2015 and 2016. Thus, our window is favorable for testing of information-driven share price movements.

We find that the shares of the 81 mainland-based firms trading in Hong Kong ( $\mathrm{H}$ shares) rose significantly relative to all other Hong Kong listings, by $1.59 \%$ and $2.26 \%$ in 3 - and 5 -day windows, respectively, around the December 4, 2012 announcement date. The portfolio of all

1 See "Wang Yukai: Central government leads drive to root out corruption" Communist Party of China News Web, December 7,2012. 
2,260 firms listed on China's two mainland exchanges, the Shanghai and Shenzhen Stock Exchanges, rose $2.77 \%$ and $3.86 \%$ in the same windows and correspond to economically significant additions of $¥ 533$ billion and $¥ 742$ billion, respectively, to the total valuations of listed businesses. These findings suggest that investors at the time viewed the Eight-Point Policy as potentially real, not as empty propaganda or a disguised purge. As the reform evolved over time, investors might have updated interpretations. However, our event study depends not on the longterm effectiveness of the reform; it merely captures investors' immediate expectations of what the news signaled.

To further examine the patterns of valuation changes, we focus on the much larger sample of mainland firms. The stocks of firms located in more liberalized provinces gained more. ${ }^{2}$ Using the National Economic Research Institute's Marketization index (Fan et al. 2011) to measure the extent of market reforms in each province, we find the portfolio of firms in high-Marketization (top tercile) provinces gain $3.20 \%$ and $4.46 \%$ in 3- and 5-day windows, respectively, around December 4, 2012. In contrast, firms in low-Marketization (bottom tercile) provinces post insignificant gains of $0.54 \%$ and $0.98 \%$ in the same windows. This is consistent with investors' expecting reduced corruption to create more value in up-and-running markets that could move resources more efficiently once obstructive corrupt officials were out of the way and little or no value where market forces could not replace bureaucratic resource allocation.

China's listed firms consist of state-owned enterprises (SOEs) and other firms (nonSOEs). SOEs in liberalized and unliberalized provinces gain similarly. However, nonSOEs in highMarketization provinces gain substantially (3.30\% and 4.38\% in the 3-day and 5-day windows), and nonSOEs in low-Marketization provinces actually decline (-2.72\% and $-3.00 \%$, respectively). These differences make sense because the anti-corruption reform targeted "leading cadres," which includes top officials and SOE executives, but not top nonSOE executives. Reduced corruption cutting waste at SOEs would boost SOE shares across the board. Reduced official corruption would free nonSOEs of obstructive tolls where market forces can move resources; but stop nonSOEs from greasing bureaucratic gears where bureaucrats still control key resources.

2 We use the term province to refer to all province-level governments, which include 23 provinces, 4 province-level cities (Beijing, Chongqing, Shanghai, and Tianjin), and 5 autonomous regions (Inner Mongolia, Guangxi, Ningxia, Tibet, and Xinjiang). 
Firm-level regressions further reveal that nonSOEs located in more liberalized provinces gain even more if the nonSOEs are more competitive (higher total factor productivity, TFP) or in more dynamic (higher growth opportunities, $Q$ ) or more finance dependent (Rajan and Zingales, 1998) sectors. This accords with investors' expecting reduced corruption to favor nonSOEs better placed to benefit from market-driven resource allocation once bureaucratic tolls fall away. It also accords with the reform boosting the relative performance of smaller firms (Giannetti et al., 2017) and improving nonSOEs' credit access (Li et al., 2017). ${ }^{3}$

Chinese annual reports itemize entertainment and travel costs (ETC). A nonSOE's past ETC might include grease payments to corrupt officials to "get things done" where officials allocate resources (Cai et al. 2011) and toll payments to get corrupt officials to step aside where market forces can allocate resources. Morck and Nakamura (1999) interpret the analogous item in Japanese annual reports as proxying for corporate insiders' private benefits, part of which might be economically efficient non-monetary compensation. Positing a firm's ETC to be a proxy for an unknown mix of all the above allows inferences about the importance of each form of ETC to different firms in different institutional environments.

Firm-level regressions show nonSOEs with higher prior ETC losing if located in the least liberalized provinces and gaining if located elsewhere. These results accord with investors' expecting reduced corruption to impede nonSOEs' essential grease payments in the least liberalized provinces and protect nonSOEs from obstructive officials' tolls elsewhere. This suggests nonSOEs' ETC is more predominantly grease payments in the least liberalized provinces and more predominantly toll payments elsewhere.

In contrast, SOEs with higher prior ETC gain regardless of location, consistent with investors viewing their ETC as capturing corporate insiders' private benefits, whose curtailment boosts valuations. However, this ETC-related boost is smaller for SOEs in more liberalized provinces, which follows if investors interpreted higher ETC as also indicating a worse-governed SOE, more apt to flounder amid stiffer competition, or as greater-nonmonetary compensation to SOE top executives, more apt to move to dynamic nonSOEs in those provinces.

We conclude that investors expected reduced corruption to create value overall in SOEs

3 SOEs have access to SOE bank loans (Cull and Xu, 2003; Allen et al., 2005) and government concessions (Xu, 2011), which nonSOEs generally lack. 
and nonSOEs, but to create more value in nonSOEs where free-market reforms are further advanced and destroy value in nonSOEs where bureaucrats alone still allocate key resources. These findings suggest that policymakers contemplating anti-corruption reforms might enact freemarket reforms first.

Our findings survive a battery of robustness checks. Additional tests that explore alternative explanations of these findings all support the interpretation above. Investors might have expected market reforms to be correlated with other reforms (e.g., enforcement effectiveness) or province characteristics (e.g., high-quality government, culture, history, education, or foreign influence) that could also complement anti-corruption reforms. We can reject many such alternatives (e.g., enforcement effectiveness), but others always remain. We, therefore, acknowledge that our conclusions, more broadly interpreted, might suggest that investors expect reduced corruption to add more to firm valuations probably by limiting connection-driven state intervention and improving resource allocation where market reforms, or other dimensions of development associated with market reforms, are more advanced and that where those preconditions are not met, reducing corruption can be expected to raise the cost of doing business. We welcome further research to explore these distinctions.

\section{Background and Event Description}

Since 1978, when market reforms ended state control over most prices, wages, and production levels, markets have assumed ever greater importance. However, market reforms remain incomplete and their operation remains subject to Party Policy (Morck and Yeung 2018) and to different degrees of legal and regulatory control in different provinces (Fan et al., 2011).

\subsection{Growing Concern about Corruption in China}

China's system of Market Socialism with Chinese Characteristics relies heavily on the discretion of Party cadres. The constitution of the People's Republic of China enshrines a Leading Role for the Communist Party of China, which gives Party Policy constitutional precedence over all laws and regulations. The precedence of Policy over laws and regulations empowers Party cadres to direct judicial verdicts and regulatory decisions to accord with Party Policy (Chen, 2003), which gives leading cadres in government and in SOEs huge discretion in applying laws and regulations and in allocating key resources and business opportunities. 
Thus, connections with a pivotal cadre open to corruption can be a high-return investment (McGregor, 2010). Krueger (1974) calls such investments "political rent-seeking." In China, the political rents firms seek can be favors to boost profits (regulatory forbearances, tax breaks, subsidies, and the like) or private benefits for top corporate insiders (personal favors, positions or advancements for relatives or associates, and the like). An official supervising greater economic activity, or exercising greater discretion, can grant favors worth more; and firms seeking those favors can consequently offer bigger bribes.

Chinese political rent-seeking is seldom overt, but rather occurs within networks of people who have established connections, or guanxi. A connection develops after lavish entertainment and other extravagant gestures between parties to the implicit contract. Exchanges involving favors and/or money can then occur within these relationships of trust. From 1978, when Deng Xiaoping launched multiple economic reforms, to 2012, China's per capita GDP rose from US\$156 to US\$6338 (both in 2017 US\$). As China's economy grew, cadres exercised undiminished discretion over rapidly escalating economic activity, with correspondingly escalating returns to political rent-seeking firms for firms and officials.

Despite Party exhortations to cadres, official corruption had become a major issue in China by the early 21 st century. In 2012, Transparency International classified China as a "highly corrupt country." Figure 1 summarizes a 2013 PEW Research Centre National Survey of Chinese respondents' top concerns reported in Financial Times (November 8, 2013). Corrupt officials come in second, behind only inflation, and are ahead of inequality, pollution, food safety, and old age security. A Central Commission for Discipline Inspection (CCDI) official warned that "the public's trust in the Party and the government has fallen to a critical level" (Xinhua, November 20, 2012).

China's increasingly well-educated and cosmopolitan population appears to have accepted the Communist Party's political monopoly in return for delivering economic prosperity. Rising corruption threatens this acceptance by creating blatant economic injustices that jar with Communist egalitarian virtues taught in schools and by impeding continued rapid growth. Sufficiently widespread corruption can slow growth if enough firms find investing in official connections becomes more profitable than investing in productivity enhancement, so economy- 
level growth can lag even as corporate profits climb (Murphy et al., 1991, 1993; Shleifer and Vishny, 1993; Mauro, 1995; Svensson, 2005; Prichett and Summers, 2014).

Widespread corruption, however, can form a stable suboptimal political economy equilibrium that locks countries into a middle-income trap (Morck et al. 2005). Powerful officials find anti-corruption reforms threatening to their personal interests, even if they recognize the public good of such reforms. Corrupt officials who are owed favors rationally oppose reforms that would prevent them from collecting what they deem their due. Corrupt officials who owe favors rationally oppose reforms that would force them to find other ways of repaying their debts or risk the consequences of failing to do so. Both fear that anti-corruption reforms would expose them to whistle-blowing and punishment. All this builds inertia. A political shock to destabilize this equilibrium then becomes a necessary precursor to effective reform.

\subsection{Political Uncertainty in $\mathbf{2 0 1 2}$}

In 2012, as the end of the previous administration's term approached, rival factions vied for power and gain. ${ }^{4}$ Which faction would win was unclear. The Washington Post wrote that Xi Jinping “disappeared mysteriously for 2 weeks. He went unseen, unheard, and undiscussed by official Chinese media," purportedly after being "hit in the back with a chair hurled during a contentious meeting of the "red second generation.", 5 Regardless of the veracity of this particular report (the Washington Post writer expressed doubts), whether Xi would emerge on top and what policies a $\mathrm{Xi}$ administration would enact remained unclear.

The Party's $18^{\text {th }}$ National Congress, from November 8 to 14,2012 , marked the official transfer of power. On November 14, 2012, Xi assumed the titles of General Secretary of the Communist Party and Chairman of the Party Central Military Commission. ${ }^{6}$ However, at the beginning of the National Congress, "former President Jiang Zemin and other party veterans

\footnotetext{
${ }^{4}$ One faction was allegedly led by Zhou Yongkang, then a member of the Standing Committee, the highest and mostpowerful CPC committee. He might also have had backing from other established and powerful political grandees. Bo Xilai, like Xi Jinping, a politically ambitious princeling (son of a Mao-era revolutionary leader) backed by Zhou Yongkang, was dismissed as Chongqing's Party Secretary on March 15, suspended from the CPC's Central Committee and its Politburo a month later, and expelled from the Party on September 28, 2012.

5 See "The secret story behind Xi Jinping's disappearance" by Max Fisher, Washington Post, November 1, 2012, https://www.washingtonpost.com/news/worldviews/wp/2012/11/01/the-secret-story-behind-xi-jinpingsdisappearance-finally-revealed/.

${ }^{6}$ Xi assumed the title of President in March 2013.
} 
returned to centre stage...demonstrating their continued power to shape the country's future" (South China Morning Post, November 8, 2012). By the end of the National Congress on November 14, Hu Jintao, the departing President of China and General Secretary of the Party, called for deepening reforms to uphold Market Socialism with Chinese Characteristics and then unexpectedly relinquished all his titles and positions (Telegraph, November 14, 2012). This unprecedented act was thought to be setting an example for future departing leaders. On November 17, 2012, $\mathrm{Hu}$ and $\mathrm{Xi}$ jointly urged "the Chinese army to be absolutely loyal and to accomplish historic missions" (Xinhua, November 17, 2012). On November 19, in a meeting with the Politburo, Xi made a speech themed "firmly uphold and develop Socialism with Chinese Characteristics" and urged the Politburo to "promote and implement the spirit of the $18^{\text {th }}$ CPC National Congress," (Xinhua, November 20, 2012). No sign of a major policy change was yet evident.

\subsection{The Eight-Point Policy}

$\mathrm{Xi}$ began his anti-corruption campaign on December 4, 2012, with a Policy document by the Politburo of the Central Committee of the Communist Party of China (CPC) entitled the "EightPoint Policy (八项规定). Each point is an explicit instruction about how leading cadres are to behave going forward. The eight points are: ${ }^{7}$

1. Leaders must keep in close contact with the grassroots, but without inspection tours or formality.

2. Meetings and major events are to be strictly regulated and efficiently arranged; empty grand gestures are to be avoided.

3. The issuance of official documents must be reduced.

4. Overseas official visits and related formalities are to be restricted.

5. Leaders traveling by car must avoid disrupting traffic.

6. Media stories about official events are to be limited to events with real news value.

7. Government leaders should not publish self-authored works or congratulatory letters.

8. Leaders must practice thrift and strictly obey regulations regarding accommodation and cars.

The inter-factional infighting before December 4, 2012, makes it highly likely that the

\footnotetext{
7 For details, see http://cpcchina.chinadaily.com.cn/2012-12/05/content_15991171.htm.
} 
Eight-Point Policy surprised investors. A preponderance of evidence also favors investors having regarded the policy as a serious anti-corruption reform (Yuen, 2014; Giannetti et al., 2017; Li et al., 2017). First, the announcement came only 20 days into the administration of President Xi Jinping. This timing was unusual because it preceded the Third Plenum, the traditional forum for announcing a new Politburo's policy reforms, by roughly a year. Second, the statement is unusually concrete in its details and free of slogans. Although it contains some familiar refrains, the document mainly specifies detailed rules. Third, almost immediately after the initial announcement, official elaborations made the new administration's anti-corruption goal clear and explained that the Eight-Point Policy was the first official policy of a sustained agenda. ${ }^{8}$

$\mathrm{Xi}$ made cutting corruption his signature policy. $\mathrm{Xi}$ assigned a central role in the campaign to Wang Qishan, who performed manual labor with Xi in Sha'anxi during the Cultural Revolution. Wang is an experienced senior Party leader with a stellar vitae: Governor of China Construction Bank (1994-7), Vice-Governor of Guangdong (1997-2002), Party Secretary of Hainan (2002-3), Mayor of Beijing (2003-7), appointed to the $17^{\text {th }}$ Politburo in 2007, Vice-Premier of the State Council in charge of finance and economics in 2008, and a member of the CPC Standing Committee, and the CCDI Secretary. Individual provinces quickly rolled out more detailed rules. For example, Tibet Autonomous Region released its own Ten Rules on December 5, 2012, itemizing how officials should reduce waste and extravagance and simplify official functions.

To verify that the Eight-Point Policy was the only major national news story on or around December 4, 2012, we use the news function in the WIND Information Database. We search through a comprehensive collection of news from different sources, including the major financial media in China, the China Securities Regulatory Commission (CSRC), People's Bank of China, Ministry of Finance, and other government organizations, and covering different areas, such as finance, business, government policy, law, and regulations. We augment this by searching major news media and internet records. These exercises reveal no other major policy announcements and confirm that the Eight-Point Policy was the only major news event in the window period.

The Policy gained immediate and widespread attention. Panel A of Figure 2 graphs internet

8 Some saw the policy as ordering corrupt cadres to be less ostentatious or as cover for a purge (Broadhurst and Wang, 2014). Consistent with this view, although each of the points can be interpreted as a directive limiting corruption, the word "corruption" actually appears in none. 
searches using Baidu, the Chinese analog of Google, using the terms "Eight-Point Policy" (八项 规定) and “anti-corruption” (反腐), both normalized by the maximum of the former within the window. The figure shows both search volumes rising sharply on Tuesday, December 4, the event date, with "Eight-Point Policy" searches peaking two 2 days later (Thursday, December 6) and "anti-corruption searches" peaking 3 days later (Friday, December 7). ${ }^{9}$

Panel B plots search volumes for terms relating to possible confounding news: "economic development” (经济发展), “economic growth” (经济增长), and “economic reform” (经济改革) alongside "Eight-Point Policy" searches, with all four normalized by the latter's maximum. The numbers of searches for all three alternative news terms remain low, and magnifying them reveals no evidence of other news-related economic policy changes in or near the event windows. We return to these issues in Section 4, which presents additional robustness checks. The Eight-Point Policy was the major standout event in this period.

The Party's subsequent actions also suggest that "the policy had teeth." Xi Jinping remarked at a plenary meeting of the CCDI in January 2013 (Xinhua, January 22, 2013) that the administration should crack down on "tigers" and "flies" in rooting out corrupt politicians, eliminating illegal activities, and curbing gift-giving and conspicuous consumption to change the general behavior of officials and renew the Party. The CCDI subsequently launched a website on which whistleblowers could report cadres' violations of the policy. ${ }^{10}$ Other statistics reinforce the veracity of the Party's commitment to enforcing the Eight-Point Policy. Sales of cigarettes, alcohol, shark fins, edible swallows, Gucci bags, and Ferraris all dropped abruptly in 2013 (Ke et al., 2016).

The above discussion validates the feasibility of an event study of the December 4, 2012

\footnotetext{
9 On November 20, 2012, searches for "anticorruption" increase slightly before the event day. This date corresponds to a Xinhua report on a CCDI submission to the $18^{\text {th }}$ National Congress about the need to eliminate corruption, mentioning that one of Xi's close allies now headed the CCDI.

${ }^{10}$ In 2013, the CCDI reported having disciplined 182,000 officials for corruption or abuse of power and 30,420 cadres specifically for violating the Eight-Point Policy. Of the latter, 227 were province-level or higher. In 2014, a series of heavyweight cadres stood convicted of corruption. These included former Politburo member Zhou Yongkang, former Central Military Commission Vice-Chairman General Xu Caihou, People's Liberation Army General and Logistics Department Deputy Leader Gu Junshan, and even retired President Hu Jintao's Personal Secretary, Ling Jihua. While all this is consistent with a serious anticorruption effort, it could also be consistent with a political power struggle. In 2014, Premier Li Keqiang continued the pledge to fight corruption promising "zero tolerance to corrupt officials" and "to seriously punish any breach of the Eight-Point anti-bureaucracy and extravagance-busting guidelines as announced by the central authorities." See http://english.www.gov.cn/premier/news/2014/08/23/content_281474983008883.htm
} 
announcement. The event date corresponds to no other confounding major news release of potentially economically important news. Stock returns around the event, therefore, plausibly reflect investors' initial expectations about what the new Policy announcement signaled.

\section{Methods and Data}

\subsection{Advantages of the Event Study Methodology in This Context}

Pervasive corruption both arises from and affects a country's institutions, broadly interpreted to include the mindsets and cultural norms of government officials, business leaders, and people in general as well as laws and regulations. This feedback probably plays out over many years, making identification challenging in firm-level or national income account data.

An event study is useful in this situation. If investors interpreted the December 4, 2012 news as a genuine suppression of corruption from that date on, stock price changes around that date reveal how investors at that time expected reduced corruption to affect different firms' prospects. To the extent that investors enfolded the impact of this whole chain of future feedback effects into their revisions of stock prices, the revisions are free of endogeneity bias.

The standard caveat to all event studies applies. Much research shows investors can be wrong, so the stock price changes we study must be interpreted as reflecting only changes in investors' expectations at the time, not how the future actually unfolds. We argued that the reform was initially widely thought to herald a major crackdown on corruption. Even if it later became something else, such as a tool for purging old guard cadres or punishing disloyalty, stock price changes when news of the reform first became public can still reflect changes in investors' expectations at that time. This caveat thus becomes an advantage in our tests.

\subsection{Sample and Description of Key Variables}

\subsubsection{Sample}

We begin with the population of all 2336 firms listed on China's two mainland stock exchanges, the Shanghai Stock Exchange and the Shenzhen Stock Exchange. Stock returns and financial data are from the China Stock Market and Accounting Research (CSMAR) database. We manually 
check whether there are corporate events in the 5-day event window surrounding December 4, 2012. We drop all firms with material corporate events, such as stock or cash dividends, stock splits or reverse-splits, new share or debt issuances, and announcements regarding mergers, restructurings, related-party transactions, or CEO turnover. This leaves 2,260 useable firms. Due to missing data, our final sample for regressions has 2024 firms.

In exploring how different stocks might react differently to the Eight-Point Policy announcement, we consider their institutional environments (the extent of market reforms in their provinces), status as an SOE or nonSOE; past spending associated with building official connections; competitiveness, growth opportunities, and external finance dependence.

\subsubsection{Extent of Market Reforms}

Whether corrupt officials primarily obstruct market forces by charging firms tolls or by charging firms for greasing bureaucratic gears to let firms "get things done" depends on the state of ambient market institutions. Where market forces are up and running, bureaucratic resource allocation is unnecessary, and bribes to corrupt officials are likely to be predominantly tolls that firms must pay to get the officials out of the way. Where markets function poorly, bureaucratic resource allocation is the only available method of accessing resources, which we call the second-best suboptimal situation.

In 2012, different provinces had implemented market reforms to different extents. More liberalized provinces had moved farther away from administered wages and prices and the command-and-control allocation of business opportunities. Their more developed market institutions were more up to the task of allocating capital, labor, and goods. Firms in these provinces thus could better rely on market forces to obtain resources. Regardless of the extent of market reforms, China's officials retained broad discretion in interpreting and implementing laws and regulations. This discretion created opportunities for corrupt officials to block firms from responding efficiently to market forces and to demand bribes for removing those blocks. Reducing corruption in more liberalized provinces then amounts to removing corrupt officials' tollbooths so firms can respond toll-free to markets. Anti-corruption reforms would thus let firms better adapt to changing market conditions, which would increase investors' valuations of firms overall.

Where market reforms were less far along, officials allocated critical resources and "greasing" bureaucratic gears could be essential to access key resources. With utility-maximizing 
officials preferring inaction to action (Wilson, 1989), ungreased bureaucratic gears could jam. In this setting, reforms that impede bribe paying could actually make doing business harder, not easier.

Of course, a province's progress towards market reforms may well correlate with other indicators of development, such as human capital or infrastructure development, which might ultimately reflect the quality of its government. A province's capacity to implement such reforms might also turn on historical factors, such as its previous exposure to commerce, entrepreneurship, and foreign ideas. We consider such alternative interpretations of our results below.

To measure the extent of market reforms, we use the province-level Marketization index produced by the National Economic Research Institute (NERI) (Fan et al., 2011). The Marketization index is based on official statistics and enterprise and household surveys. The index

rises as the private sector shares of output, investment, and employment rise; price controls and trade barriers fall; factor markets (labor, finance, and investment) are liberalized; and the legal environment improves. The index is scaled to range from zero to ten in the base year 2001, with higher scores indicating more progress toward a market economy. It can exceed ten or fall below zero in subsequent years to reflect a province's progress or retrogression over time. This index is widely regarded as a meaningful measure of the progress of pro-market reforms (Wang et al., 2008; Fan et al., 2011).

Table I reports the 2011 Marketization index for each province. The five most economically liberalized province-level economies are Zhejiang, Jiangsu, Shanghai, Guangdong, and Beijing; the least liberalized are Tibet, Qinghai, Gansu, Xinjiang, and Guizhou.

\subsubsection{Firm Type: SOEs and nonSOES}

China has two broadly defined classes of listed firms, state-owned enterprises (SOEs) and nonstate-owned firms (nonSOEs). SOEs enjoy favorable official treatments, such as preferential access to bank loans, which are the dominant form of financing in China (Cull and Xu, 2003; Allen et al., 2005). Some SOEs have state-enforced monopolies in key sectors, including natural resources, civil aviation, communications, and finance (Chen et al., 2011), or other government concessions $(\mathrm{Xu}, 2011)$. The Party, via its human-resources arm, the Organization Department, determines the careers of SOE top managers, who have formal and typically high ranks as both 
Party cadres and civil servants. Their career paths typically move them from one SOE to another and in and out of government every 3 or 4 years, with moves to better positions depending on their faithful implementation of Party Policy and directives, as well as on the performance of the SOE or state organ under their charge (Wu et al., 2014; Deng et al., 2015).

This arrangement has three implications. First, SOE top managers, as leading cadres and civil servants, are directly subject to the Eight-Point Policy. Second, SOEs depend less than nonSOEs on connections to "get things done" and are less vulnerable to toll extraction because SOE top executives and the officials who regulate SOEs are all ultimately under the common and control of the Party. Third, SOEs might well still spend money on connections, but this spending is more apt to be designed to advance their top managers' careers than to benefit their shareholders; thus, it falls under the heading of private benefits.

NonSOE top executives, in contrast, often have substantial equity ownership stakes in their firms and have careers tied to their firms' prospects (Conyon and Lerong, 2011). NonSOEs, not intrinsically connected to the civil service, cannot rely on the Party's command-and-control mechanisms to align government officials' interests with their own. Indeed, government officials may even erect artificial regulatory barriers in the paths of nonSOEs as tollbooths to extract bribes (Cull and $\mathrm{Xu}, 2005)$. Moreover, nonSOEs have less access than SOEs to state-owned bank loans, capital markets (e.g., initial public offerings) (Cull and Xu, 2003; Allen et al., 2005; Firth et al., 2009; Piotroski and Zhang, 2014), and official licenses to enter new lines of business. Park and Luo (2001) note, "It is not surprising to find that private firms were often left out of business opportunities due to a lack of materials even if their products were popular in the market." Thus, nonSOEs must contend with more (and more severe) bureaucratic obstacles, many of which may exist primarily for bribe extraction, than SOEs confront.

These considerations suggest that genuinely reducing corruption would affect SOEs and nonSOEs differently in different provinces in the following ways.

Where markets function well, reducing corruption bars officials from charging tolls for removing artificial roadblocks that obstruct nonSOEs' responses to market forces. Where resources are still allocated by command and control, reducing corruption bars officials from accepting the bribes nonSOEs' must pay to get bureaucratic gears moving to get things done. This reasoning suggests that investors, interpreting the Eight-Point Policy as reducing corruption, 
would assign higher valuations to nonSOEs in more liberalized provinces and lower valuations to nonSOEs in less liberalized provinces.

The above reasoning pertains to nonSOEs. SOEs are charged with implementing Party goals and the leading cadres in both SOEs and government are both subject to Organization Bureau discipline should they impede Party goals. The Eight-Point Policy applies directly to SOE top managers, barring them from paying or accepting bribes and from using their SOE's resources to advance their private interests. If investors viewed the Eight-Point Policy announcement as reducing SOE top cadres' wasteful private benefits, they might value SOEs more highly. Alternatively, if those private benefits were incentives to attract talent to SOEs, investors might attach lower valuations to SOEs likely to suffer an exodus of talent.

To classify firms as SOEs or nonSOEs, we begin with all firms with 2011 data in the China Listed Private Enterprise Research Database (CLPERD), which contains firms that CSMAR classifies as "private enterprises." This list includes all firms so classified in any year between 2003 (the beginning year of the database) and 2011. We crosscheck this list against 2011 data on controlling shareholders from the China Listed Firm's Shareholders Research Database (GTA_HLD), which identifies major equity blockholders and their control and cash flow rights, following La Porta et al. (1999). We double-check these data by manually collecting 2011 ownership structure data for all listed firms from the Sina Finance database (http://finance.sina.com.cn), paying special attention to conflicts between two prior approaches. These steps give us a tentative roster of nonSOEs in 2011 and information about all listed firms' major direct shareholders that year.

To identify ultimate controlling shareholders, we construct control chains as follows. First, we identify other listed firms' stakes in each listed firm, which allows us to build control chains from each listed firm to an ultimate controlling entity that is unlisted. We say an ultimate controlling shareholder controls a firm if the minimum control block, what La Porta et al. (1999) call the weakest link, in the control chain connecting them is at least $30 \%$. This threshold accords with CSRC guidelines, issued on December 16, 1997, for inferring control, and it aligns with the definition in CSMAR data. We then use company websites and Baidu searches to classify these ultimate controlling shareholders as either state (state or Party organs) or non-state (all other) entities. In many cases, this requires identifying the ultimate controlling shareholders of unlisted 
holding companies or other investment vehicles. State entities include central, provincial, city, or municipal-level governments, state-controlled institutions, and state-controlled investment vehicles, such as State-owned Assets Supervision and Administration Commissions (SASACs). We say a firm is an SOE if it is ultimately controlled by a state entity, so defined, and as a nonSOE otherwise. These manual searches lead us to reclassify 87 firms as SOEs.

Our approach likely understates state control, as many nonSOEs are indirectly statecontrolled via ostensibly nonSOE holding companies run by officials. Moreover, all firms of any note have Party Committees and Party Secretaries to assist their boards and CEOs. Nonetheless, the SOE designation plausibly reflects a more direct Party role in governance, a closer alignment of top executives' interests with those of cadres in the civil service, and the preferential treatment by government officials and the major banks, all of which are SOEs.

\subsubsection{Investment in Connections}

Prior work suggests that reducing corruption diminishes the value of a firm's prior investment in connections (Fisman, 2001). To investigate this, we take listed firms' reported Entertainment and Travel Costs $(E T C)$ as a proxy for firms' corruption-related expenditures. We interpret this variable as an unknown combination of legitimate expenses, investment in connections to grease bureaucratic gears where bureaucrats allocate resources, toll payments to officials where bureaucrats obstruct market forces and private benefits for the firms' top insiders. By reducing expected future corruption, the Eight-Point Policy would affect different firms differently according to the composition of their ETC.

We posit that the ETC of nonSOEs in less liberalized provinces, where bureaucrats move resources, plausibly has a larger bureaucratic gear greasing component, whereas the ETC of nonSOEs in more liberalized provinces, where markets can move resources but for bureaucrats' toll barriers, plausibly has a larger toll component. If so, investors would view reduced expected future corruption as more detrimental to high-ETC nonSOEs in less liberalized provinces (firms that had to spend more greasing gears), but more beneficial to high-ETC nonSOEs in more liberalized provinces (firms that had to spend more on bureaucratic tolls). If so, share price changes around the announcement of the Eight-Point Policy would correlate negatively with prior ETC for nonSOEs in less liberalized provinces and positively with prior ETC for nonSOEs in more 
liberalized provinces.

We posit that neither grease payments nor tolls likely loom large in SOEs' ETC because the Party assigns SOEs policy goals, such as elevating GDP growth, and Communist Party compensates and promotes officials for their harmonious advancement of Party policies. Rationally corrupt bureaucrats who readily demand tolls or grease payments from nonSOEs would avoid the career risk of so treating SOEs and being found to have impeded a Party policy. This leaves private benefits to top executives the plausibly most prominent component of SOE ETC. NonSOE ETC might also include private benefits to executives, but the Eight-Point Policy directly affects private benefits top of SOE top executives because they are leading Party cadres. SOE executives' private benefits can be direct (perks or nepotism) or indirect (using SOE resources to bribe others to provide perks or nepotism). This overall line of reasoning suggests that an SOE's shares would rise in proportion to its prior ETC if investors viewed thee private benefits as waste. However, if investors viewed top SOE executives' private benefits as perks to attract talent, SOE shares might fall in anticipation of a talent flight.

We construct our ETC variable using data manually collected from Chinese listed firms' annual reports. Under Chinese accounting principles, entertainment costs $(E C)$ and travel costs (TC) are secondary accounting items reported for each fiscal year in notes to the Income Statement lines for Management Expenses or Sales Costs (or both). An annual report can include up to four such notes. Chinese accounting principles allow substantial leeway about which costs go under which notes. Moreover, different firms sometimes use different Chinese terms for these costs (e.g., accommodation costs, business trip costs) and disclose them in different formats. Finally, some firms report neither $E C$ nor $T C$.

Inspection of annual reports shows firms reporting $E C$ or TC or both and doing so under Management Expenses, Sales Costs, or both. In some cases, a firm may report under different headings in different years, with none at all reported in some years. To allow for variation in reporting practices, we construct our primary ETC measure as follows: We first take ETC as the sum of all (i.e., under either Management Expenses or Sales Costs) EC and TC in 2011. In 28 cases, the firm reports neither EC nor $T C$ in 2011, but reports one or both in 2010, and we take its ETC to be the sum of all EC and TC in 2010. ETC for the remaining firms is treated as missing.

This approach is necessarily ad hoc, so we construct alternative measures of ETC in a range 
of ways. One alternative is not to fill in the 28 cases with missing 2011 data using 2010 data, but just treat these as missing. Another presumes that firms reporting neither $E C$ nor $T C$ in 2011 actually do have zero ETC in 2011. Still another sets ETC to zero if a firm reporting neither EC nor $T C$ in 2011 and the three prior years, but treats ETC as missing if the firm reports either in any of those prior years. The results in the tables are preserved using these alternative ETC measures, and are occasionally significant in places where our primary ETC measure is not.

\section{Empirical Findings}

\subsection{The Reaction of the Market}

We first examine stock price reaction to the anti-corruption policy using the 81 mainland stock listings in Hong Kong. We then turn to the larger sample of stocks trading in the two mainland stock exchanges - Shenzhen and Shanghai.

Figure 3 shows the cumulative return of the portfolio of the 81 mainland stocks rising abruptly relative to the portfolio of all other Hong Kong stocks around the event date. These gains are not quickly reversed and are therefore unlikely to be driven by trading pressure (temporary imbalances between supply and demand). The 3-day cumulative return of the portfolio of Hong Kong-listed mainland shares is a significantly positive $1.89 \%(\mathrm{p}<1 \%)$; the 5 -day cumulative return of the portfolio is also significantly positive: $2.83 \%(\mathrm{p}<5 \%)$. This contrasts with the insignificant $+0.40 \%$ and +0.573 - and 5-day cumulative returns, respectively, for the portfolio of all other Hong Kong stocks. The difference-in-differences of $1.59 \%$ and $2.26 \%$ for the 3- and 5day windows, respectively, are highly significant ( $\mathrm{p}<0.001$ for both).

Because foreign investors have unrestricted access to the Hong Kong market, listed mainland companies' share prices can be interpreted as gauging Hong Kong and international investors' expectations about the reforms. These results are consistent with these investors viewing the Eight-Point Policy announcement on December 4, 2012, as positive economic news for mainland firms. The sample of 81 Hong Kong-listed Chinese firms is very small, only $3.6 \%$ the size of the full sample of mainland stocks, and too small to allow meaningful cross-sectional 
comparisons. $^{11}$

Table II summarizes the share price reactions of Chinese firms listed on the mainland exchanges in two windows: a 3-day window $[-1,+1]$, from the trading day before the December 4, 2012 announcement to the trading day after, and a 5-day window [-2, +2], beginning two trading days before the announcement date and ending two trading days after. The market portfolio gains $2.77 \%$ in the 3 -day window and $3.86 \%$ in the 5-day window, and both figures are statistically significant. ${ }^{12}$ Both are also economically significant, representing $¥ 533$ billion and $¥ 742$ billion increases, respectively, in investors' valuations of corporate assets. These findings accord with investors viewing the Eight-Point Policy as important and, on the net, value-creating across all listed firms. These findings also suggest that investors did not view the policy as merely signaling a factional power struggle.

These returns are not reversed. Instead, the event date emerges as an inflection point for the market return: the end of a bear market and the onset of a bull market. This is evident in Figure 4, which presents a value-weighted cumulative total (adjusted to include dividends and account for splits) market return. An equal-weighted cumulative total market return similarly shows that the event-date portfolio-valuation changes persist.

Table II further shows that the Eight-Point Policy announcement increased the share prices of firms in more liberalized provinces. The second and third rows of Table II show the returns of portfolios of firms in provinces at different stages of liberalization. The 3-day window cumulative return on the portfolio of firms in the highest-tercile Marketization provinces is $3.20 \%$ and statistically significant. In the 5-day window, the same portfolio rises by a statistically significant $4.46 \%$. In contrast, the cumulative 3-day window return of the portfolio of firms in the lowesttercile Marketization provinces is a statistically insignificant $+0.54 \%$. In the 5 -day window, this portfolio registers an insignificant increase of $+0.98 \%$. The differences between the portfolios of firms in the highest- versus lowest-tercile Marketization provinces in the 3- and 5-day windows are $2.66 \%$ and $3.49 \%$, respectively; both are highly statistically significant. The finding of more

\footnotetext{
${ }^{11}$ They also may not be representative of mainland-listed stocks (Hung et al., 2012). Furthermore, most of these shares are not cross-listed on mainland exchanges, and Hong Kong accounting rules do not mandate disclosure of entertainment and travel costs.

${ }^{12}$ In testing the significance of all these portfolio's returns, we use the estimated historical standard deviation using data from 210 to 11 trading days before the event date.
} 
positive share price moves for firms in more liberalized provinces is consistent with investors having viewed reduced future corruption more as clearing away toll-collecting officials in more liberalized provinces.

The divergence in the valuations of the portfolio of firms in high- versus low-Marketization provinces is not ephemeral. The cumulative return from a hedge position, going long in highMarketization province stocks and shorting low-Marketization province stocks, is substantial and is not quickly reversed, as it would be were temporary price pressure magnifying the divergence. Depending on when the position is closed, the gain ranges from just below zero to just above $3 \%$. Closing the positions on an average day in the two trading weeks (ten event days) after the end of the 5-day event window nets a statistically and economically significant $1.76 \%(p=0.06)$. Closing the positions on an average day between the end of the 5-day event window and 30 trading days after the event date likewise nets $1.50 \%(\mathrm{p}=0.04)$. These reactions are consistent with investors taking the December 4, 2012 event as economically significant and expecting the announced reforms to reduce future corruption.

\subsection{Market Development, SOEs, and nonSOEs}

Section 3.2.3 argues that the anti-corruption reform would affect SOEs and nonSOEs differently. Panels A and B of Table II compare the cumulative returns over 3- and 5-day event windows, respectively, centered on December 4, 2012, of the portfolios of SOEs versus nonSOEs and of the sub-portfolios of SOEs and nonSOEs in the highest- versus the lowest-tercile Marketization provinces.

The portfolio returns accord with this argument. First, consistent with investors expecting the Eight-Point Policy to cut wasteful private benefits at SOEs, the portfolio of all SOEs and the sub-portfolios of SOEs in provinces with high- and low-Marketization indexes all have positive and statistically significant returns.

Second, consistent with investors expecting the Eight-Point Policy to keep nonSOEs from making grease payments to unjam bureaucratic gears where inaction-prone officials (Wilson, 1989) allocate resources, nonSOEs in the lowest-tercile Marketization provinces have cumulative losses; those in the 3-day window are significant. In contrast, the portfolio of nonSOEs in the highest- 
tercile Marketization provinces gain significantly.

Third, the portfolio of SOEs outpaces that of nonSOEs by a wider margin in the bottomthan in the top-tercile Marketization provinces. Specifically, within the 3-day window, in lowMarketization provinces the portfolio of SOEs gains a statistically significant $5.99 \%$ more than does the portfolio of nonSOEs. In high-Marketization provinces, the SOE and nonSOE portfolios have statistically indistinguishable returns, and the point estimates put the SOE portfolio gain only $0.25 \%$ above that of the nonSOE portfolio. In the 5-day window, the corresponding numbers are a statistically significant $7.38 \%$ and an insignificant $0.13 \%$, respectively. These results are consistent with investors expecting reduced corruption to add more value to nonSOEs where market institutions were better developed and where bribing officials more predominantly meant paying bureaucratic tolls. To further investigate these issues, we turn to firm-level regression analyses.

\subsection{Firm-Level Regressions}

We next explore how the individual stocks that compose these portfolios move by regressing stock price reactions to the anti-corruption reform on firm and industry characteristics and their interactions with the Marketization index of the firm's province. These characteristics include firm-level Total Factor Productivity (TFP), estimated as in Levinsohn and Petrin (2003); Growth Potential (Q), defined as industry-average Tobin's q (market-to-book ratio); and External Finance Dependence $(E F D)$, defined as industry-average capital expenditures minus cash flow from operations over capital expenditures (Rajan and Zingales, 1998). ${ }^{13}$ If investors expected the anticorruption reform to raise allocative efficiency more in more liberalized provinces, larger gains should be evident in the stocks of more competitive firms, firms in industries with more growth opportunities, and firms in industries needing more external financing in those provinces. Thus, the regressions include interactions of the Marketization index with each of these variables. The regressions also include firm-level ETC, which, as explained in Section 3.2.4, reflects some combination of a firm's past spending on connections useful for "getting things done," tolls extracted by obstructive officials, private benefits for corporate insiders, and non-monetary

${ }^{13}$ Both Growth Potential and External Finance Dependence are defined as simple industry-averages. A robustness check using value-weighted industry averages generates similar results. 
compensation, each depending on the level of Marketization.

The regressions explore these empirical propositions by including cross-terms of Marketization with $E T C, T F P, E F D$, and $Q$. The regressions also include explanatory variables Marketization, ETC, and TFP main effects; industry fixed-effects subsume those of $E F D$ and $Q$.

The regressions control for measures of the province-level business environments: provincial GDP Growth, $\log ($ GDP per capita), and Education Spending as a fraction of GDP. These controls capture a location's generic economic development. The regressions also control

for Firm Leverage (total liabilities over total assets), which mechanically amplifies equity valuation changes associated with changes to asset valuations, as well as Firm Size (log of total assets) and Research and Development Spending (R\&D/sales) to allow for shares of small firms and firms with more intangible assets moving systematically differently. Industry fixed effects remove common reactions across industries. Clustering is bidirectional, by both industry and province. All explanatory variables are lagged 1 year; they are 2011 data. Table III reports their means and standard deviations in the full sample and in the sub-samples of SOEs and nonSOEs used for the regressions.

Given the very different patterns of results for the portfolios of SOEs and nonSOEs revealed in Table II, we run separate regressions for the two categories of firms. Table IV reports the results, with the regressions in Panels A and B explaining 3-day and 5-day firm-level cumulative returns, respectively. Industry fixed effects essentially leave the Table IV regressions explaining cumulative abnormal returns, defined as returns minus industry mean returns.

\subsubsection{Market Institutions, Firm Characteristics, and Stock Price Reactions}

In both panels of Table IV, Marketization attracts highly statistically significant positive coefficients in regressions (1). The analogous coefficients in (3) are negative, and that in panel A is statistically significant $(\mathrm{p}=10 \%)$. NonSOEs in more liberalized provinces thus gain more in reaction to the Eight-Point Policy; while SOEs in more liberalized provinces gain less (or lose more). Like patterns emerge for Education Spending, another indicator of provincial development, although this variable is insignificant in the SOE regressions.

Focusing on Marketization and using regressions (1) and (3) in Panel A to illustrate, a one 
standard deviation increase in Marketization is associated with a $0.37 \%$ 3-day gain for nonSOEs, but a $0.35 \% 3$-day decline for SOEs. Pooling the data and running a regression containing an SOE dummy and interactions reveals the differences to be statistically significant. Thus, investors expect reduced corruption to be more beneficial for nonSOEs where more liberalized markets can better guide resource allocation. In contrast, investors expect reduced corruption to be less helpful (or more harmful) to SOEs where market reforms are more advanced, perhaps because they expect the reform to unfetter market forces for which previously cossetted SOEs are ill-prepared.

Regressions (2) and (4) elaborate on these findings by including interactions of Marketization with the firm and industry characteristics described above: the industry-level variables Growth Potential $(Q)$ and External Finance Dependence $(E F D)$ and the firm-level variables Total Factor Productivity (TFP) and Entertainment and Travel Costs (ETC). The highly significant joint $F$-tests of the Marketization main effect and its interactions with these variables, shown near the bottom of each panel, justify exploring the economic significance of the individual interaction terms.

In regression (2) of Panel A, where the dependent variable is the 3-day window cumulative returns of nonSOEs, the province-level Marketization main-effect becomes insignificant $(\mathrm{p}=0.58)$; however, its interactions with firm-level TFP, industry-level $Q$, and industry-level $E F D$ are all positive and significant, both individually and jointly. The same pattern emerges in the 5-day window regression (2) in Panel B. These results are consistent with investors expecting nonSOEs in more liberalized provinces to gain more from reduced corruption if they are also more productive or in sectors with more growth opportunities or more need for external capital.

More generally, these findings are consistent with investors expecting the Eight-Point Policy to reduce future corruption, with this removing bureaucratic obstacles to market forces and adding value to nonSOEs in provinces with better-developed markets, and with the added value greater for nonSOEs better positioned to benefit from stronger market forces. Being better positioned here means being more competitive and in more dynamic or more external financedependent sectors. This set of results is consistent with investors expecting reduced corruption to lower bureaucratic tolls, unleash market forces, and improve allocative efficiency.

Regressions (4), explaining SOE cumulative returns, show intermittent significance in the cross-terms of Marketization with Growth Potential (positive and insignificant in Panel A, but 
significant in Panel B), External Finance Dependence (negative and insignificant in Panel A, but significant in Panel B), and Total Factor Productivity (negative and significant in Panel A, but insignificant in Panel B). This instability in the interaction coefficients leaves us reluctant to draw economic inferences.

Table IV also links past ETC to event window returns after controlling for firm-, industry-, and macro-level characteristics. Regression (1) in Panel A shows nonSOEs with higher past ETC gaining less. Regression (2) in Panel A elaborates, showing ETC's main-effect term to be a negatively significant -0.136 and its interaction with Marketization to be a positively significant 0.029. These coefficients imply that, where Marketization is above 4.69 (all provinces except Qinghai and Tibet), a nonSOE's stock gain more if its ETC is higher. The corresponding regression results in Panel B yields the same conclusion. Thus, the regressions show ETC negatively related to a nonSOE'.' cumulative returns only in the two least liberalized provinces. Elsewhere, the relationship is positive and increasingly so in more liberalized provinces.

These results are consistent with investors expecting the Eight-Point Policy to curtail corruption and viewing nonSOE ETC as more predominantly toll fees in more liberalized provinces and more predominantly greasing bureaucratic gears in the least liberalized provinces.

SOEs' ETC shows a starkly different pattern. In both panels, SOEs with higher ETC gain insignificantly in regression (3), though the coefficient is significant at $10 \%$ in a one-tail test in Panel B. In both panels, regression (4) show the ETC main effect to be positive and significant while ETC's interaction with Marketization is negative and significant. Repeating the arithmetic above for SOEs shows that ETC correlates positively with SOEs' stock price gains only in Tibet, the least economically liberalized province. Elsewhere the correlation is negative, and more negative in higher Marketization provinces.

These results are consistent with investors expecting the Eight-Point Policy to increase SOEs' valuations by reducing their ETC spending on private benefits, but also expecting SOEs with high prior ETC spending to be less able to cope with stiffened market pressure in more liberalized provinces as bureaucratic tolls restraining nonSOEs fall away. Higher-ETC SOEs might confront greater problems in more liberalized provinces for several reasons. Higher ETC might proxy for lower quality SOE management, which investors expect to be a bigger problem after reduced corruption unleashes stronger market forces. Alternatively, higher ETC might be a perk 
to attract higher quality management to an SOE, which investors expect reduced to eliminate, again leaving high-ETC SOEs with lower quality top management to contend with stronger market forces. ${ }^{14}$ All of these considerations combine to explain why investors would expect reduced corruption to more adversely affect less well managed SOEs where market forces are stronger.

\subsection{Important Potential Alternative Interpretations}

One of our key results is that the anti-corruption reform boosts nonSOE share prices more in more liberalized provinces. A province's Marketization is taken as gauging its progress in implementing market reforms. Hence, our result is consistent with anti-corruption reforms unleashing latent market forces, which disproportionately helps more competitive nonSOEs in provinces with more complete market reforms. Importantly, this interpretation links the positive effects of the anticorruption reform to the strength of market forces.

However, some alternative interpretations merit consideration. These turn on whether the Eight-Point Policy event signals reduced future corruption or something else, such as a broader commitment to further market reforms, and on whether the Marketization index gauges the development of market institutions or something else, such as better quality government. The following discussion explores these alternative interpretations in detail.

\subsubsection{Economic Reforms versus Anti-corruption Reforms}

We interpret event window stock returns as reflecting investors' reactions to news that future corruption would be reduced, rather than news about policy stability, that is, that economic reforms would continue. Although the Eight-Point Policy was unambiguously an anti-corruption measure, discussion about further economic reforms was ongoing. For example, the World Bank's "China 2030" study, urging continued reforms, circulated after February 2012 and was formally published on March 23, 2013. Moreover, economic and anti-corruption reforms are not unrelated, so our interpretation must be justified.

\footnotetext{
${ }^{14}$ Top managers have lower monetary compensation, but more job security and power, in SOEs than in nonSOEs.
} 
Our primary justification is the Internet search graphs in Figure 2. Consistent with the Eight-Point Policy announcement causing investors to expect reduced corruption, rather than renewed general economic reform, Internet searches for anti-corruption spiked around news of the Eight-Point Policy, whereas searches for economic reform did not.

In addition, many of our results are most readily explained if investors viewed the EightPoint Policy as heralding reduced corruption, rather than renewed general economic reforms. If investors presumed that further general economic reforms would disproportionately benefit firms in provinces whose market reforms were already further along, some of our results might follow. This is possible, but not a priori obvious because a central reinvigoration of the economic reform process might have the greatest impact where reforms had stalled. Provinces whose market reforms were already well along might have less left to do.

Moreover, some of our findings are difficult to explain if investors did not expect the EightPoint Policy to curtail corruption. One such finding is that SOE shares rise with ETC. If they interpreted the Eight-Point Policy as signaling more reforms to come, this pattern suggests investors expected such reforms to include restraints on SOE top executives' private benefits that is to curtail a form of corruption.

Another is nonSOE shares dropping with ETC in less liberalized provinces, but rising with ETC in more liberalized provinces, which is not obviously explicable if the Eight Point Policy merely signaled deeper economic reform to come, but is readily explained by reduced corruption impeding nonSOEs from making essential grease payments in lower Marketization provinces and impeding corrupt officials from charging obstructive tolls in higher Marketization provinces.

\subsubsection{Market Machinery versus Enforcement}

Provinces with more advanced market reforms might be better run generally, and investors might expect better-run provinces to enforce the anti-corruption reform better. Better-enforced reforms could boost share prices more in those provinces. Furthermore, better enforcement might also explain the larger gains by nonSOEs with higher past ETC in higher Marketization provinces. This result would follow if investors viewed nonSOE ETC more as toll payments in more liberalized provinces and expected better enforcement of the anti-corruption reform to more thoroughly 
eradicate tolls in those provinces. However, although investors may indeed have expected more effective enforcement in higher Marketization provinces, several lines of reasoning weigh against the Marketization index primarily proxying for effective enforcement and in favor of it reflecting progress in market reforms.

First, if the reform were well enforced in high Marketization provinces and ill-enforced in low Marketization provinces, Table II would show more positive returns for the highMarketization portfolios and less positive or insignificant returns for low-Marketization portfolios. In fact, the low-Marketization nonSOE portfolio has large significantly negative returns in the 3day window. This would result if investors expected the reforms to be well enforced in those provinces, disabling ways of greasing bureaucratic wheels and raising the cost of doing business. Indeed, the Party discipline is plausibly stronger, not weaker, in less reformed provinces, so Party policies are likely to be more rigorously enforced in less liberalized provinces. For instance, China's least liberalized province-level jurisdiction, Tibet, was the first to show support of the Eight-Point Policy by releasing its own Ten Rules on December 5, 2012, itemizing how cadres in Tibet should reduce waste and extravagance and simplify official functions.

Furthermore, the arithmetic calculations presented above in connection with the Table IV regressions show nonSOEs' share price reactions around news about the Eight-Point Policy to be negatively related to ETC for firms in Tibet and Qinghai, the two lowest Marketization provinces. The negative ETC combined effect in these provinces is inconsistent with enforcement being ineffective in those provinces, but is readily explicable if the anti-corruption policy is well enforced, but markets work poorly in those provinces. Moreover, bigger gains for SOEs with higher prior ETC in low Marketization provinces accords with investors viewing ETC as private benefits, which they expect reduced corruption to curtail.

\subsubsection{Marketization and a Stronger Developmental Response}

Provinces with stronger market machinery might also have better quality governments, which better promote market institutions, which improve resource allocation. These provinces might also have larger pools of well-educated potential top executives better able to boost firm productivity. Both SOEs and nonSOEs might react to a less corrupt business environment by replacing old top managers, whose expertise is connection-building, with new ones whose expertise is increasing 
productivity. If investors expected this shift to be more complete in more liberalized provinces, our results might follow.

More generally, we accept that different forms of institutional development overlap and interact. The Marketization index might reflect other province-level institutional characteristics such as a culture more supportive of entrepreneurship, a history of commercial activity, greater openness to foreign ideas, or any other latent factor that, when intervention by corrupt officials is blocked, promotes better resource allocation. Such characteristics might reinforce any positive impact investors expect reduced future corruption to have on a firm's future prospects. We take the Marketization index as its formulators present it, as a measure of each province's progress towards free markets; but accept that it might proxy for any of the aforementioned other institutional characteristics. We welcome further research exploring alternative explanations of our findings.

\subsection{Robustness Discussion}

The first robustness issue is the newsworthiness of our event. Information leakage is a potential concern in event studies. Figure 2 shows internet searches for anti-corruption” (反腐) rising slightly shortly before a much larger spike on and immediately after our event date. Checking news reports revealed a November 20, 2012, Xinhua article describing a CCDI submission to the $18^{\text {th }}$ National Congress on the need to eliminate corruption immediately. The date was just after the handover of power from the old to the new administration and might be an alternative event date if investors viewed the CCDI submission as marking a genuine crackdown on corruption, rather than a reiteration of Politburo rhetoric condemning corruption.

To explore this possibility, we examine stock returns around November 20, 2012. In contrast to the significant positive reactions evident around the event date of December 4, 2012, the market return in a 3 -day window around November 20, 2012, is an insignificant $0.82 \%$. The 5 -day cumulative return is $-0.54 \%$ and insignificant. This exercise supports the validity of the news on December 4, 2012, as a surprise, which fits our event framework for exploring the economic implications of investors' expectations of decreased corruption. 
Another possible confounding event occurred on December 7, 2012, when Xi visited Shenzhen. The event is widely hailed as Xi signaling that the economic reforms launched by Deng Xiaoping in December 1992 would continue under his administration and also that Xi himself was practicing the principles laid out in the Eight-Point Policy. ${ }^{15}$ This news received much less media coverage than the Eight-Point Policy announcement. Nevertheless, we rerun our tests using a (-1, +4) window, which stretches from December 3 to December 8, 2012. The results are similar to those in the tables, though in the analog of Table 4 SOE regressions, the cross-term results and main effect of $E T C$ become insignificant.

Second, our findings survive a battery of standard robustness checks. Where a robustness check generates a pattern of signs and statistical significance identical to that in the tables, and point estimates roughly concordant to those in the tables, we say qualitatively similar results ensue. Where qualitatively similar results do not ensue, we explain the discrepancies in detail.

To ensure that our results are not driven by outliers, we winsorize firm-level cumulative returns at $1 \%$ before running the regressions in Table IV. The regression results are qualitatively similar if we do not winsorize the returns. A more conservative approach repeats the regressions, excluding observations whose estimated residuals exceed \pm 2.5 times the standard deviations of the residuals. Qualitatively similar results ensue.

To ensure that our results are not driven by unusual provinces, we first exclude firms located in Tibet, whose cultural, social, political, and economic characteristics differ substantially from those of other provinces. This generates qualitatively similar results. We next exclude firms based in Beijing and Shanghai because these are China's most developed province-level jurisdictions and because firms with nationwide operations tend to be headquartered in them. ${ }^{16}$ This also generates qualitatively similar results. Finally, we drop firms based in Beijing, Shanghai, and Tibet to ensure that the results do not depend on the contrast between China's most and least developed provinces. This generates qualitatively similar results.

Financial and real estate firms are regulated differently from other firms, and listed firms

\footnotetext{
15 "Echoes of Deng Xiaoping as Xi Jinping heads to Shenzhen on first inspection trip," South China Morning Post, December 7,2012, describes Xi sending "a signal of commitment to deepening reform," projecting a "low profile," and "banning empty talk by officials and excessive pomp for tours." See

${ }^{16}$ Firms in Beijing are plausibly subject to the lowest cost monitoring and strongest control by the central government (Huang et al. 2017).
} 
in these sectors have national operations. Dropping firms in finance, real estate, and both sectors all yield qualitatively similar results.

The ETC variable is missing for 12\% (264 of 2260) of all firms for which all other data are available and that had no confounding news during the event window. We substitute 2010 ETC for missing 2011 data to fill in 11\% (28 of 264) of these firms to obtain our sample for the ETC regressions in Table IV. Thus, 88\% of firms that reported no ETC in 2011 also reported none in 2010. One possible concern is that these firms might either genuinely have insubstantial ETC in some years or systematically manipulate their reporting to avoid disclosing ETC. Our results are robust to setting ETC to zero where it is missing in 2011, to setting ETC to zero where it is missing in both 2010 and 2011, and to dropping observations with missing ETC in 2011.

Likewise, our results in Table II, where we tabulate comparisons of returns on the market portfolio, SOE and nonSOE portfolios as well as their sub-portfolios grouped by top and bottom terciles of provinces by Marketization, are obtained using the full sample including firms with missing ETC observations. The patterns in terms of magnitude and statistical significance are qualitatively identical if we drop observations with missing ETC, and regardless of whether or not we winsorize the returns at $1 \%$.

We use total assets to measure firm size and scale $R \& D$ and $E T C$ by total sales. Re-running our tests using total assets to scale $R \& D$ and $E T C$ yields qualitatively similar results.

The explained variable in the Table IV regressions is the event window cumulative total return of each stock. Because the regressions include industry fixed-effects, the operational explained variable is the firm's cumulative abnormal return, defined as the stock return minus the mean return of all stocks in its industry, a widely used event study methodology. Using simulations, Thompson (1988) shows that cumulative abnormal returns calculated in this way generate results imperceptibly different from cumulative abnormal returns generated from standard asset pricing models. Furthermore, a serious campaign against corruption may well change the risk environment, and, therefore firms' risk factor loadings. Putting these issues aside, we repeat the Table IV regressions using 3- and 5-day event window cumulative abnormal returns. They are calculated as cumulative returns minus cumulative estimated market model returns, using the contemporaneous market return and market model parameters estimated using data from trading day -210 to day 11 , where day 0 is the event date of December 4, 2012. The coefficients of primary interest are 
those of Marketization, ETC, and the interactions of Marketization with industry $Q$ and External Finance Dependence and with firm-level Total Factor Productivity and ETC. All are qualitatively similar to Table VI, save that the interaction of Marketization with Q loses significance in the SOE regression (4) analogous to Panel B of Table VI.

The firm-level tests cluster separately by industry and province (two-way clustering). Rerunning the tests clustering by industry only, province only, or industry-province cell all generate identical signs and point estimates to those in the tables; however, they have higher $\mathrm{t}$ ratios in many cases. Therefore, we present two-way clustering results as the most conservative.

\section{Conclusions}

Mitigating corruption can unleash market forces and immediately improve resource allocation (e.g., Murphy et al., 1993; Shleifer and Vishny, 1993; Mauro, 1995; Fisman and Svensson, 2007).; yet, can have a short term negative economic impact where bribery is essential to bureaucratic gears where markets work poorly and bureaucrats control key resources (e.g., Fisman, 2001; Wei, 2001; McMillan and Woodruff, 2002; Li et al., 2008.).

On December 4, 2012, the Communist Party of China unexpectedly announced its EightPoint Policy, initially widely perceived as an order to curtail official corruption by banning leading cadres, including officials and SOE top executives, from providing or accepting extravagant private benefits. This event provided a natural experimental setting for testing investors' views on the impact of reduced corruption on firms with different characteristics and in provinces with different degrees of free-market reforms. We find that market development determines which view is most relevant in different Chinese provinces. Our empirical findings and their implications are:

1. On December 4, 2012, when the Eight-Point Policy was announced, the shares of mainland Chinese companies trading in Hong Kong posted abnormal returns economically and statistically significant positive abnormal returns relative to other Hong Kong stocks, and stocks trading on the mainland exchanges posted economically and statistically significant gains overall.

These findings are consistent with investors expecting the policy to curtail official corruption and this to create value overall. They support prior work arguing that curtailing 
corruption has economy-level benefits (Krueger, 1974; Murphy et al., 1991, 1993; Shleifer and Vishny, 1993; Mauro, 1995).

Regardless of whether or not these expectations turned out to be correct over subsequent years, the pattern of stock price movements in narrow windows around December 4, 2012, contains information about how investors expected curtailed corruption to play out across the Chinese economy. Specifically,

2. Investors expected curtailed official corruption to deter SOE top executives from providing private benefits to themselves and this to increase SOE values. However, investors also expected these increases to be more strongly counterbalanced by SOEs' challenges in contending with stronger market forces in more liberalized provinces. Investors further expected these challenges to be greater for SOEs with higher past spending on entertainment and travel.

The last of this set of findings could follow high private benefits spending reflects poor governance, using perks to keep talented managers, or both. In either case, higher private benefits spending indicates SOE less apt to prosper amid lower corruption environment and strengthened market forces. Our results suggest that governments entertaining SOE reforms might wish to focus initially on improving SOE governance and the quality of SOE top executives. Cutting SOE top management compensation (e.g., the April 2016 decision to cut SOE bank CEOs' pay by half) does not contribute to attracting and retaining the talent SOEs need to survive market competition.

3. Investors expected curtailed official corruption to deter officials from accepting private benefits in return for favors, expected this to unleash market forces, and expected stronger market forces to have a greater real impact on nonSOEs in more liberalized provinces, in which markets were more fully up and running.

Investors could also have expected the Eight-Point Policy to presage further reforms in the longer run, perhaps more so in more liberalized provinces, better able to implement such reforms

4. Investors expected curtailed official corruption to adversely affect nonSOEs in the least liberalized provinces, where markets functioned poorly, and bureaucrats allocated key resources. NonSOEs in these provinces lost more value if they had previously spent more on entertainment and travel. 
This set of findings suggests that nonSOEs must "grease bureaucratic gears" to access resources in the least liberalized provinces; and that investors expected reduced corruption to more adversely affect nonSOEs in these provinces that had invested more in such grease payments.

5. Investors expected curtailed official corruption to bring about greater improvements in allocative efficiency and competitive pressure in more liberalized provinces. Specifically, more productive nonSOEs in industries with greater growth potential and more need for external financing gained more in provinces whose market reforms were more advanced. Moreover, these gains were larger for nonSOEs that had previously spent more on entertainment and travel.

This set of findings argues that corruption in more liberalized provinces is more predominantly nonSOEs paying corrupt officials to lift toll barriers. Curtailing corruption, by lifting these barriers, creates value. This final set of results also reinforces the view that corruption renders resource allocation suboptimal (Krueger, 1974; Murphy et al., 1993; Shleifer and Vishny, 1993; Mauro, 1995; Fisman and Svensson, 2007; Ayyagari et al., 2014).

The fourth and fifth sets of findings are consistent with market liberalization complementing reforms that reduce corruption. If markets are up and running, corruption more predominantly takes the form of officials erecting artificial barriers in the paths of firms responding to market forces and charging those firms tolls to remove the barriers. Under these conditions, corruption becomes a fee for doing business, and curtailing it creates value by eliminating these unnecessary fees so market forces can better allocate resources and eliminate waste.

If markets are not up and running, and bureaucrats allocate resources, corruption more predominantly takes the form of otherwise inaction-prone officials taking bribes to let firms access needed resources. Under these conditions, corruption becomes a routine and economically necessary business practice and curtailing corruption harms firms by preventing them from paying officials to grease jammed bureaucratic gears.

That corruption can become an essential business practice in such environments may explain why anti-corruption reforms often fail (see, Fjeldstad and Isaksen 2008; Johnston 2005; Lawson 2009; Meagher 2005; Svensson 2005; and Persson, Rothstein and Teorell, 2013). Our findings suggest an important vulnerability in such systems of entrenched corruption. More extensive market liberalization moves corrupt officials out of the role of providing essential gear- 
greasing services and into the role of charging obstructive tolls. Reforms that eliminate obstructive tolls are apt to encounter less insurmountable opposition than would reforms that impede essential services.

Our results point to market liberalization as the critical determinant of whether corruption is more predominantly tolls or gear-greasing. However, provinces that are further along in establishing markets may well be further along in other dimensions of institutional development. If so, the extent of market development might also be proxying for other aspects of institutional development such as government quality, education, or even social behavioral norms. We find the Marketization measure uniquely empirically powerful. None of a range of alternative institutional development measures shows similar explanatory power, and including these alongside the Marketization index leaves the basic results above unchanged. However, distinguishing highly correlated variables subject to different or unknown measurement error problems is econometrically problematic, especially here where interaction coefficients are of critical interest (Leamer 1978, pp. 170-81). We consequently cannot preclude future research showing other dimensions of institutional development to be important. However, the findings enumerated above readily fit together if market development is a critical factor.

Finally, stock markets are not strong form efficient. However, even if shareholders' expectations prove incorrect, an event study can accurately measures shareholders' expectations in this case, about the impact of reduced future corruption across firms and provinces. Substantial evidence shows that the Eight-Point Policy was initially perceived as a broad-based attack on corruption. Despite increasing suspicion that the policy has become something other than that, the event study results remain economically useful as evidence of what investors expected to happen following a general drop in corruption. 


\section{References}

Agarwal, S., Qian W., Seru A., and Zhang J., 2019. Disguised corruption: Evidence from consumer credit in China. Journal of Financial Economics, Forthcoming.

Alesina, A., and Angeletos, G.M., 2005. Corruption, inequality, and fairness. Journal of Monetary Economics 52(7), 1227-1244.

Allen, F., Qian, J., Qian, M., 2005. Law, finance, and economic growth in China. Journal of Financial Economics 77, 57-116.

Ayyagari, M., Demirguc-Kunt, A., and Maksimovic, V., 2014. Bribe payments and innovation in developing countries: Are innovating firms disproportionately affected? Journal of Financial and Quantitative Analysis 49(01), 51-75.

Broadhurst, R., and Wang, P., 2014. After the Bo Xilai trial: Does corruption threaten China's future? Survival: Global Politics and Strategy 56, 157-178.

Cai, H., Fang, H., and Xu, L.C., 2011. Eat, drink, firms and government: An investigation of corruption from entertainment and travel costs of Chinese firms. Journal of Law and Economics 54, 55-78.

Calomiris, C.W., Fisman, R., and Wang, Y., 2010. Profiting from government stakes in a command economy: Evidence from Chinese asset sales. Journal of Financial Economics 96, 399412.

Carpenter, J.N., Lu, F., and Whitelaw, R., 2020. The real value of China's stock market. Journal of Financial Economics, Forthcoming.

Chen, S., Sun, Z., Tang, S., and Wu, D., 2011. Government intervention and investment efficiency: Evidence from China. Journal of Corporate Finance 17, 259-271.

Chen, T., and Kung, J.K.S., 2019. Busting the "Princelings": The campaign against corruption in China's primary land market. The Quarterly Journal of Economics 134(1), 185-226.

Chen, Z., 2003. Capital markets and legal development: The China case. China Economic Review $14,451-472$.

Conyon, M., and Lerong, H., 2011. Executive compensation and corporate governance in China. Journal of Corporate Finance 17, 1158-75.

Cull, R., and Xu, L.C., 2003. Who gets credit? The behavior of bureaucrats and state banks in allocating credit to Chinese state-owned enterprises. Journal of Development Economics 71, 533-559.

Cull, R., and Xu, L.C., 2005. Institutions, ownership, and finance: The determinants of profit reinvestment among Chinese firms. Journal of Financial Economics 77(1), 117-146.

Deng, Y., Wu, J., Morck R., and Yeung B., 2015. China's pseudo monetary policy (previously titled: Monetary and fiscal stimuli, ownership structure and China's housing market), Review of Finance 19, 55-93.

Fan, G., Wang, X., and Zhu, H., 2011. NERI index of Marketization of China's provinces: 2011 report (in Chinese). Economic Science Press, Beijing.

Firth, M., Lin, C., Liu, P., Wong, S.M.L., 2009. Inside the black box: Bank credit allocation in China's private sector. Journal of Banking \& Finance 33, 1144-1155. 
Fisman, R, 2001. Estimating the value of political connections. American Economic Review 91(4), 1095-1102.

Fisman, R., and Miguel, E., 2007. Corruption, norms, and legal enforcement: Evidence from diplomatic parking tickets. Journal of Political Economy 115, 1020-1048.

Fisman, R., and Svensson, J., 2007. Are corruption and taxation really harmful to growth? Firm level evidence. Journal of Development Economics 83, 63-75.

Fisman, R., and Wang, Y., 2015. Corruption in Chinese privatizations. The Journal of Law, Economics, \& Organization 31(1), 1-29.

Fisman, R., Shi, J., Wang, Y., and Xu, R., 2018. Social ties and favoritism in Chinese science. Journal of Political Economy 126(3), 1134-1171.

Fjeldstad, O.-H., and Isaksen, J., 2008. Anti-corruption reforms: Challenges, effects and limits of World Bank support. World Bank Independent Evaluation Group (IEG) Report, World Bank External Series Working Paper No. 7.

Giannetti, M., Liao G., You, J., and Yu X., 2017. The externalities of corruption: Evidence from entrepreneurial activity in China. Working paper.

Giannetti, M., Liao, G., and Yu, X., 2015. The brain gain of corporate boards: Evidence from China. The Journal of Finance 70(4), 1629-1682.

Huang, Z., Li, L., Ma, G., and Xu, L.C., 2017. Hayek, local information, and commanding heights: Decentralizing state-owned enterprises. American Economic Review 107(8), 2455-2478.

Hung, M., Wong, T., and Zhang, T., 2012. Political considerations in the decision of Chinese SOEs to list in Hong Kong. Journal of Accounting and Economics 53, 435-449.

Jia, C., Wang, Y., and Xiong, W., 2017. Market segmentation and differential reactions of local and foreign investors to analyst recommendations. The Review of Financial Studies 30(9), 2972-3008.

Johnston, M., 2005. Syndromes of Corruption: Wealth, Power, and Democracy. Cambridge, UK: Cambridge University Press.

Ke, B., Liu, N., and Tang, S., 2016. The effect of anti-corruption campaign on shareholder value in a weak institutional environment: Evidence from China. Working paper presented in Asia Bureau of Finance and Economic Research.

Krueger, A.O., 1974. The political economy of the rent-seeking society. The American Economic Review 64, 291-303.

La Porta, R., Lopez-de-Silanes, F., and Shleifer, A., 1999. Corporate ownership around the world. Journal of Finance 54 (2), 471-517.

Lawson, L., 2009. The politics of anti-corruption reform in Africa. Journal of Modern African Studies 47 (1)73-100.

Leamer, E.E., 1978. Specification Searches: Ad Hoc Inference with Nonexperimental Data (Vol. 53) : John Wiley \& Sons Incorporated.

Levinsohn, J., and Petrin, A., 2003. Estimating production functions using inputs to control for unobservables. Review of Economic Studies 70, 317-341. 
Li, B., Wang Z., and Zhou, H., 2017. China's anti-corruption campaign and credit reallocation from SOEs to non-SOEs. PBCSF-NIFR Research Paper, Tsinghua University.

Li, H., Meng, L., Wang, Q., and Zhou, L.-A., 2008. Political connections, financing and firm performance: Evidence from Chinese private firms. Journal of Development Economics 87, 283-299.

Liu, L.X., Shu, H., and Wei, K.J., 2017. The impacts of political uncertainty on asset prices: Evidence from the Bo scandal in China. Journal of Financial Economics 125(2), 286-310.

Mauro, P., 1995. Corruption and growth. The Quarterly Journal of Economics 110 (3), 681-712.

McGregor, R., 2010. The Party: The Secret World of China's Communist Rulers. Penguin UK.

McMillan, J., and Woodruff, C., 2002. The central role of entrepreneurs in transition economies. Journal of Economic Perspectives 16, 153-170.

Meagher, P., 2005. Anti-corruption agencies: Rhetoric versus reality. The Journal of Policy Reform 8(1), 69-103.

Morck, R., and Yeung, B., 2018. East Asian financial and economic development. In Handbook of Finance and Development, eds. Ross Levine and Thorsten Beck. Edward Elgar.

Morck, R., Nakamura, M., 1999. Banks and corporate control in Japan. Journal of Finance 54, 319-339.

Morck, R., Sepanski, J., and Yeung, B., 2001. Habitual and non-habitual lobbyists in the US steel industry: An EM algorithm approach. Economic Inquiry 39 (3), 365-378.

Morck, R., Wolfenzon, D., and Yeung, B., 2005. Corporate governance, economic entrenchment and growth. Journal of Economic Literature 43, 657-722.

Murphy, K.M., Shleifer, A., and Vishny, R.W., 1991. The allocation of talent: Implications for growth. Quarterly Journal of Economics 106, 503-30.

Murphy, K.M., Shleifer, A., and Vishny, R.W., 1993. Why is rent-seeking so costly to growth? American Economic Review 83, 409-414.

Park, S.H., and Luo, Y., 2001. Guanxi and organizational dynamics: Organizational networking in Chinese firms. Strategic Management Journal 22, 455-477.

Persson, A., Rothstein, B., and Teorell, J., 2013. Why anticorruption reforms fail—systemic corruption as a collective action problem. Governance 26(3), 449-471.

Piotroski, J.D., and Zhang, T., 2014. Politicians and the IPO decision: The impact of impending political promotions on IPO activity in China. Journal of Financial Economics 111, 111136.

Pritchett, L., and Summers L.H., 2014. Asiaphoria meet regression to the mean. Harvard Kennedy School M-RCBG working paper, 2014-04.

Rajan, R.G., and Zingales, L., 1998. Financial dependence and growth. American Economic Review 88, 559-587.

Rajan, R.G., and Zingales, L., 2003a. The great reversals: The politics of financial development in the twentieth century, Journal of Financial Economics 69 (1), 5-50. 
Rajan, R. G., and Zingales, L. 2003b. Saving capitalism from the capitalists: Unleashing the power of financial markets to create wealth and spread opportunity, Crown Business, ISBN 9780-609-61070-1.

Schwert, G.W., 1981. Using financial data to measure effects of regulation. Journal of Law and Economics 24, 121-158.

Shleifer, A., and Vishny, R., 1993. Corruption. Quarterly Journal of Economics 108, 599-617.

Svensson, J., 2005. Eight questions about corruption. The Journal of Economic Perspectives 19, $19-42$.

Thompson, J. E., 1988. More methods that make little difference in event studies. Journal of Business Finance and Accounting 15, 77-86.

Wang, Q., Wong, T.-J., and Xia, L., 2008. State ownership, the institutional environment, and auditor choice: Evidence from China. Journal of Accounting and Economics 46, 112-134.

Wei, S.-J., 2001. Corruption in economic transition and development: Grease or sand? United Nations Economic Commission for Europe, Geneva.

Wilson, J. Q., 1989. Bureaucracy: What government agencies do and why they do it. Basic Books.

Woo, W.T., 2012. A new economic growth engine for China: Escaping the middle-income trap by not doing more of the same. World Scientific.

World Bank, 2015. World Bank Group Integrity Vice-presidency Annual Report. Washington: World Bank Group.

Wu, J., Deng Y., Huang, J., Morck, R., and Yeung, B., 2014. Incentives and outcomes: China's environmental policy. Capitalism and Society 9(1), 2. (NBER WP18754)

$\mathrm{Xu}, \mathrm{C} ., 2$ 2011. The fundamental institutions of China's reforms and development. Journal of Economic Literature 49, 1076-1151.

Yuen, S., 2014. Disciplining the party. Xi Jinping's anti-corruption campaign and its limits. China Perspectives, 41-47.

Zeume, S., 2017. Bribes and firm value. The Review of Financial Studies 30 (5), 1457-1489.

Zhao, M., Fogel, K., Morck, R., and Yeung, B., 2011. Trade liberalization and institutional reform. Asia Economic Paper 9 (2), 44-71. 
Figure 1: Fraction of Chinese Respondents Viewing Issues as a "Big Problem"

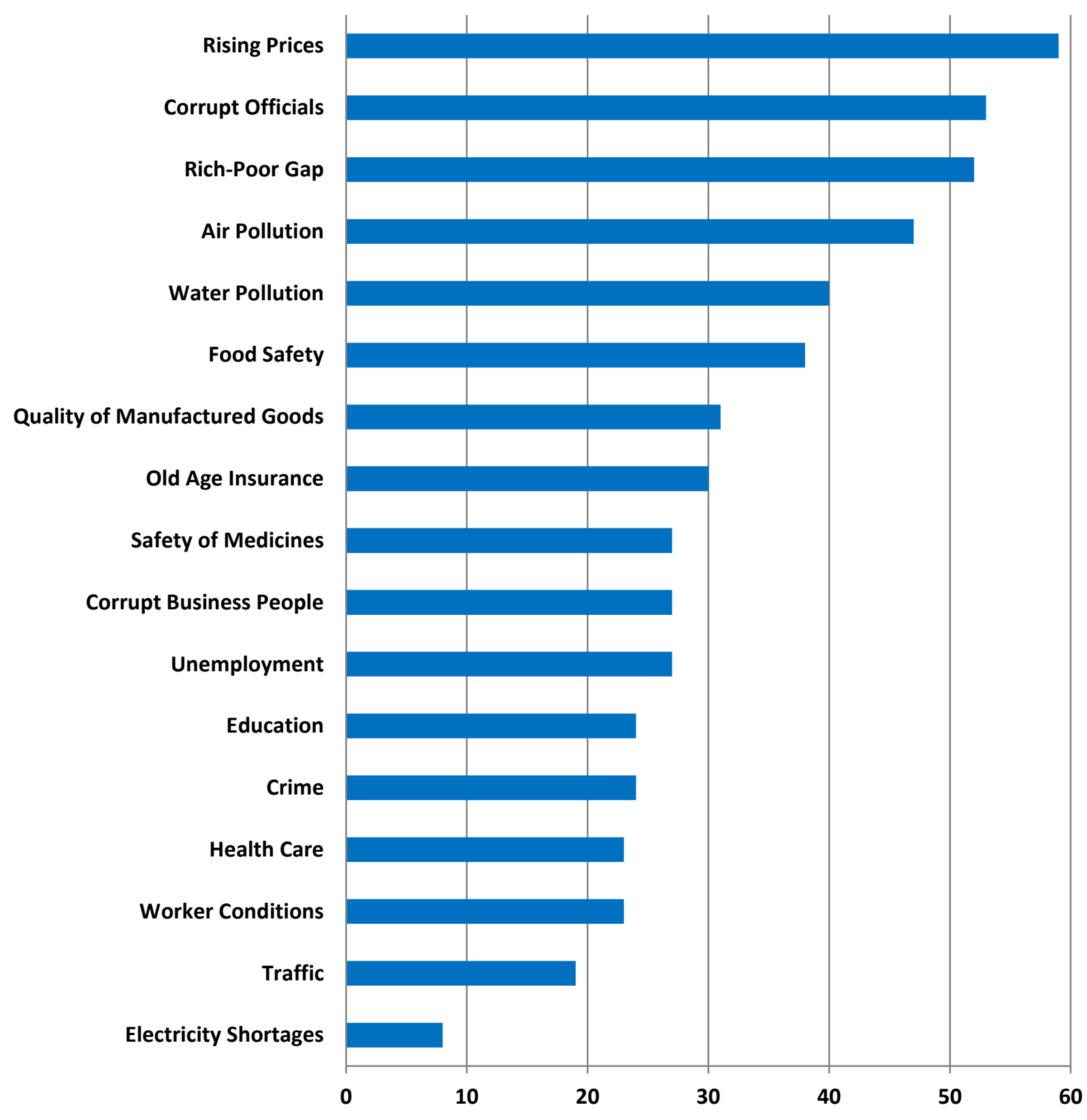

Source: PEW Survey Research Center, Spring 2013 PEW Research Center Survey, reported in the November 8, 2013, Financial Times article, "Inflation, corruption, inequality top list of Chinese public's concerns." The horizontal axis measures percentage of Chinese respondents who found the issue to be a "very big problem." 


\section{Figure 2: Online Attention to the Eight-Point Policy}

Panel A: Daily Baidu internet search volume for 'Eight-Point Policy’ (in Chinese, 八项规定), indicated by the solid line, and for “anti-corruption" (反腐), indicated by the dashed line. The event date, Tuesday, December 4, 2012, is indicated by the dark gray band. The medium and light gray bands mark the 3- and 5-trading day windows, respectively, around it. The last spans a weekend. Search volumes are scaled by the maximum for 'Eight-Point Policy' searches, which occurred on Thursday, December 6, 2012.

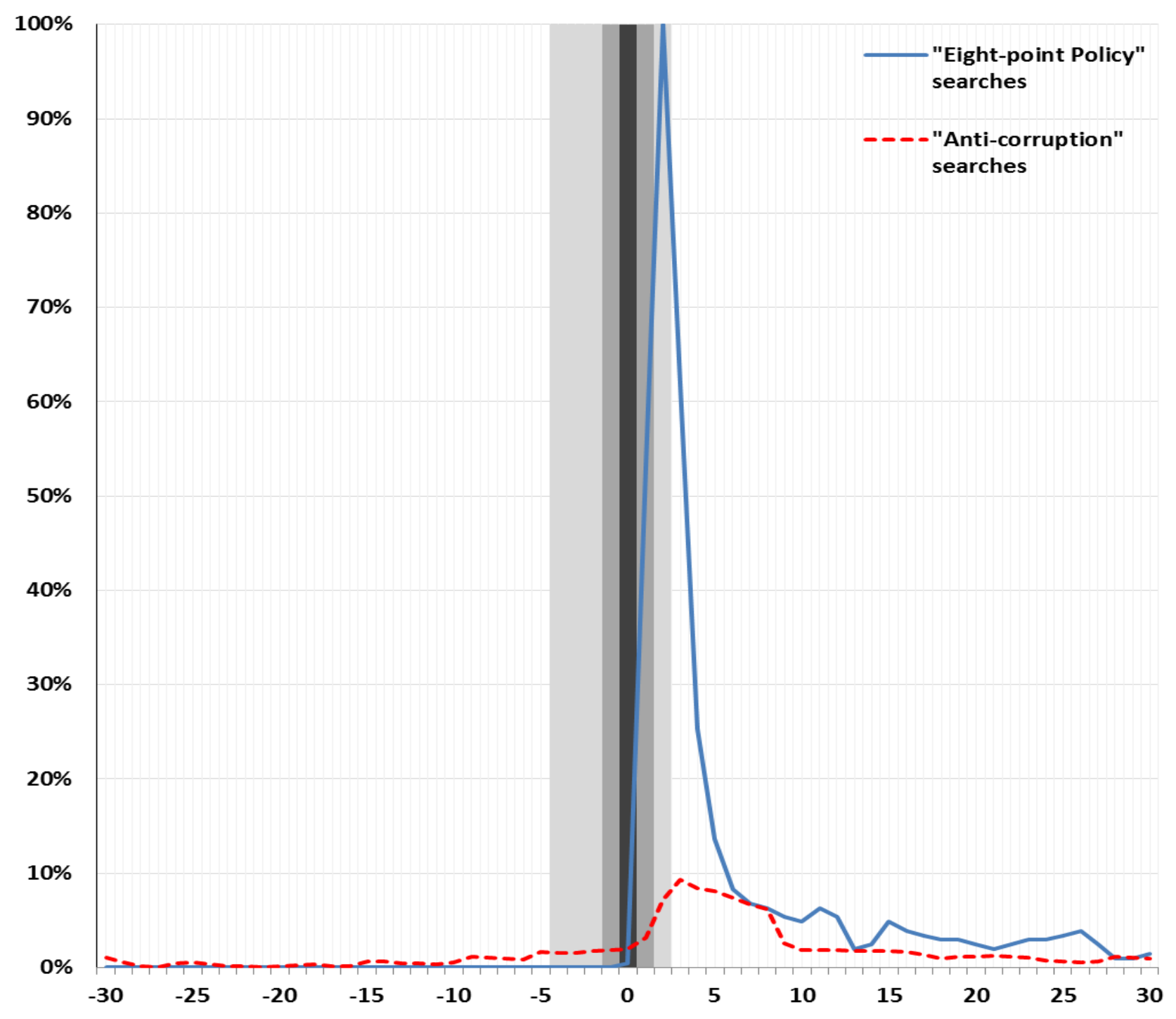




\section{Figure 2. Online Attention to the Eight-Point Policy (Continued)}

Panel B. Daily Baidu internet search volume for 'Eight-Point Policy’ (in Chinese, 八项规定), indicated by the solid line, and for “economic development” (经济发展), “economic growth” (经济增长), and “economic reform” (经济改 革), indicated by successively finer dashed lines.. The event date, Tuesday, December 4, 2012, is indicated by the dark gray band. The medium and light gray bands mark the 3- and 5-trading day windows, respectively, around it. The last spans a weekend. Search volumes are scaled by the maximum for 'Eight-Point Policy' searches, which occurred on Thursday, December 6, 2012.

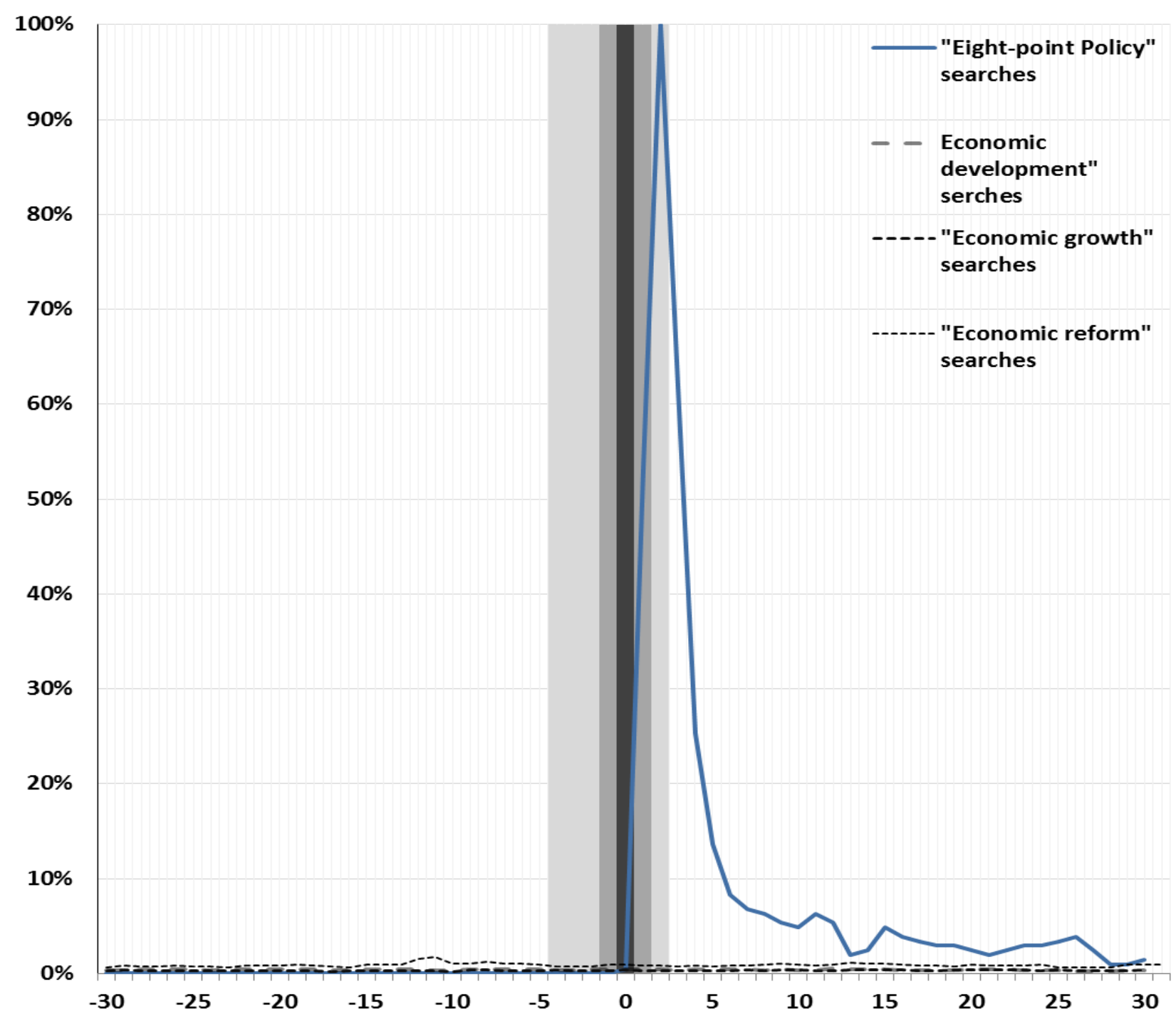


Figure 3. Mainland Chinese Firms Listed in Hong Kong versus Other Hong Kong Firms

The cumulative total return indexes of all mainland firms (H shares) listed on the Hong Kong Stock Exchange and all other stocks listed there, plotted before and after the event date, December 4, 2012, on which the Party adopted the Eight-Point Policy to curtail corruption in the Party's ranks of leading cadres. Both indexes are normalized to $100 \%$ at the beginning of the five5-trading day event window surrounding the event date.

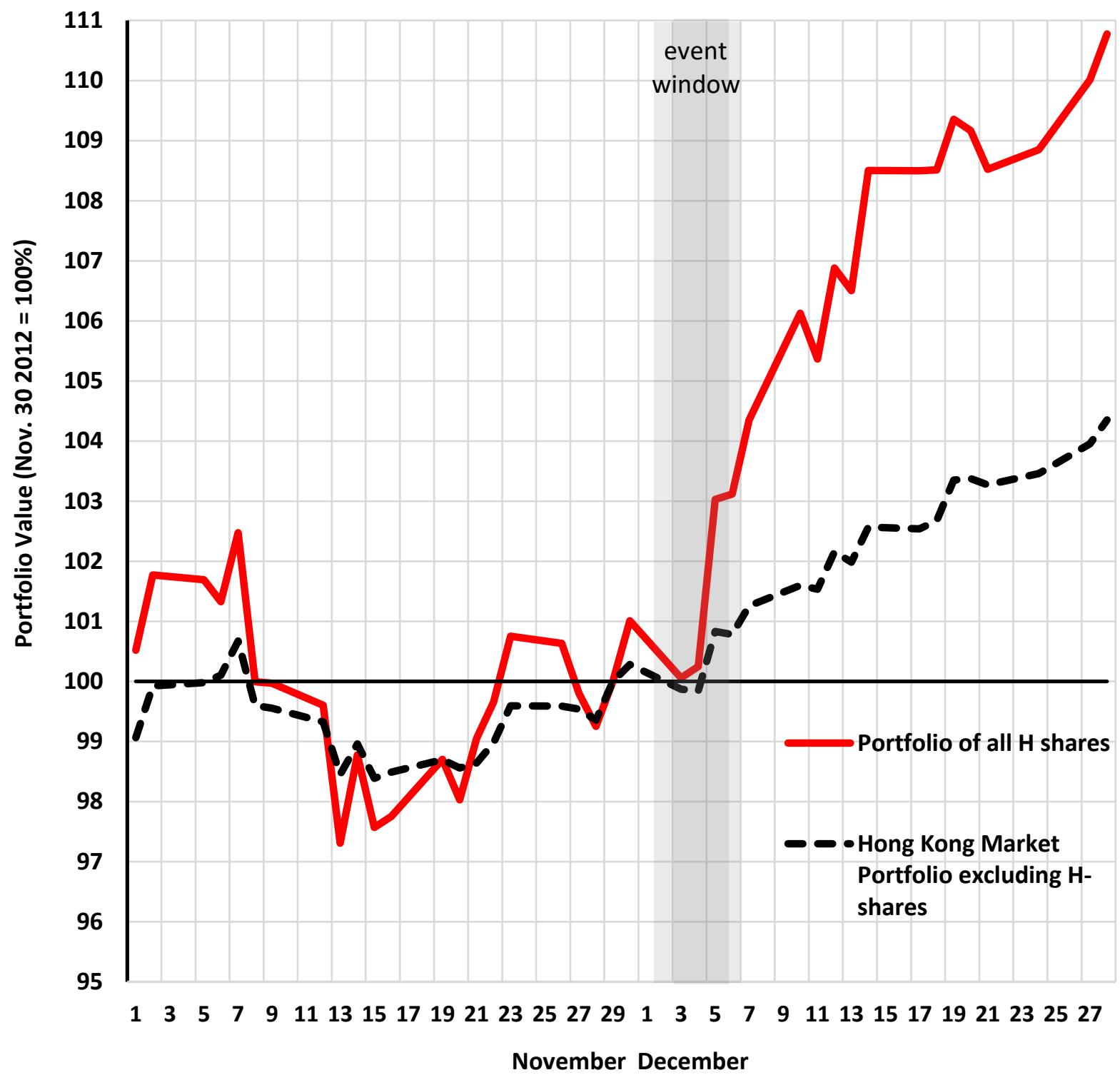




\section{Figure 4. Chinese Market Index before and after the Initiation of the Eight-Point Policy}

The cumulative return of a value-weighted portfolio of all listed shares on China's two mainland stock exchanges, the Shanghai Stock Exchange and the Shenzhen Stock Exchange. Successively darker gray bands indicate 5-and 3-trading day event windows and the event date, December 4, 2012, when the Party adopted the Eight-Point Policy to curtail corruption in the Party's ranks of leading cadres.

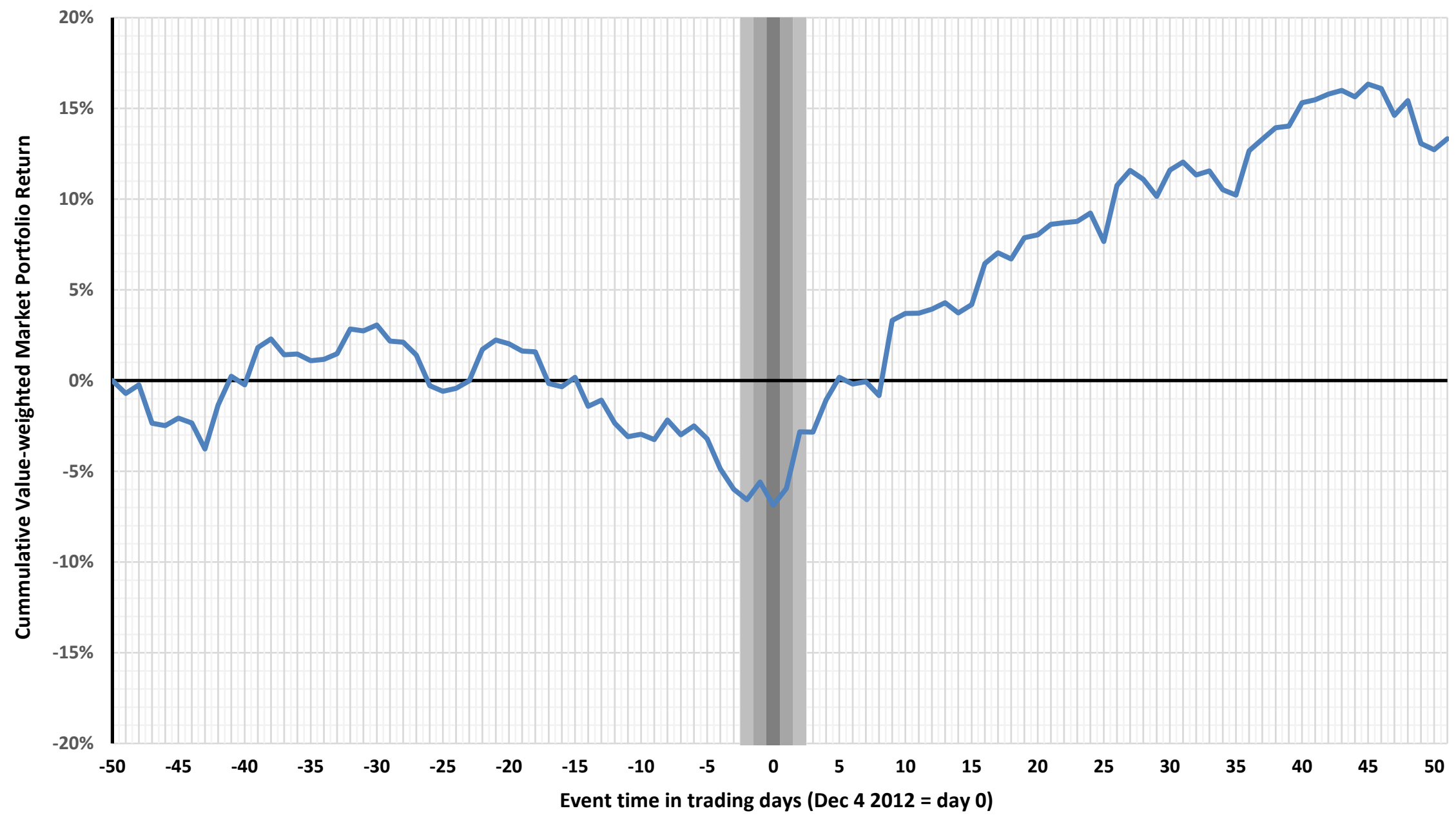




\section{Table I}

\section{Marketization Index by Province-level Jurisdiction}

A higher Marketization index indicates more progress toward implementing market reforms. Provincelevel jurisdictions include provinces, province-level cities and autonomous regions. Indexes and subindexes are described in detail in Appendix I.

\begin{tabular}{lclc} 
Province & Marketization & Province & Marketization \\
\hline 1. Zhejiang & 11.8 & 17. Hebei & 7.3 \\
2. Jiangsu & 11.5 & 18. Jilin & 7.1 \\
3. Shanghai & 11.0 & 19. Hainan & 6.4 \\
4. Guangdong & 10.4 & 20. Inner Mongolia & 6.3 \\
5. Beijing & 9.9 & 21. Guangxi & 6.2 \\
6. Tianjin & 9.4 & 22. Shanxi & 6.1 \\
7. Fujian & 9.0 & 23. Heilongjiang & 6.1 \\
8. Shandong & 8.9 & 24. Yunnan & 6.1 \\
9. Liaoning & 8.8 & 25. Ningxia & 5.9 \\
10. Chongqing & 8.1 & 26. Shaanxi & 5.7 \\
11. Henan & 8.0 & 27. Guizhou & 5.6 \\
12. Anhui & 7.9 & 28. Xinjiang & 5.1 \\
13. Jiangxi & 7.7 & 29. Gansu & 5.0 \\
14. Hubei & 7.7 & 30. Qinghai & 3.3 \\
15. Sichuan & 7.6 & 31. Tibet & 0.4 \\
16. Hunan & 7.4 & & \\
\hline Soure: & & & .
\end{tabular}

Source: National Economic Research Institute (NERI) data, as reported by Fan et al. (2011) 


\section{Table II}

\section{Stock Market Reaction and Differentiated by Marketization}

This table reports value-weighted cumulative stock returns of market portfolios around the announcement of the Eight Point Policy on Dec. 4, 2012. Portfolios contain all firms, non-state-owned enterprises (nonSOEs) only, or state-owned enterprises (SOEs) only; firms in all provinces, low-Marketization (bottom tercile) provinces or high-Marketization (top tercile) provinces, and all combinations thereof. Marketization gauges provinces' progress in implementing market reforms. Differences between nonSOEs and SOEs and between stocks in high- versus low-Marketization provinces are also computed. Panel A uses a 3-day event window. The standard deviation used to test whether $C R(-1,1)$ differs significantly from zero is the square root of 3 times the variance of daily stock returns from day -211 to day -11 . Panel B uses a 5-day window. The standard deviation used to test whether $C R(-2,2)$ differs significantly from zero is the square root of 5 times the variance of daily stock returns from day -211 to day -11 . Significance at the $10 \%, 5 \%$, and $1 \%$ level is indicated by $* * *$, and $* * *$, respectively.

Panel A. Mean 3-day cumulative returns, $C R(-1,1)$

\begin{tabular}{cllll} 
& All firms & nonSOEs & SOEs & $\begin{array}{c}\text { nonSOE } \\
\text { minus SOE }\end{array}$ \\
\hline All provinces & $2.77^{*}$ & 2.44 & $2.94 * *$ & $-0.51^{* * *}$ \\
Low Marketization provinces & 0.54 & $-2.72^{*}$ & $3.27^{*}$ & $-5.99^{* * *}$ \\
High Marketization provinces & $3.20^{* *}$ & $3.03^{*}$ & $3.28^{* *}$ & -0.25 \\
High minus low Marketization provinces & $2.66^{* * *}$ & $5.75^{* * *}$ & 0.01 &
\end{tabular}

Panel B. Mean 5-day cumulative raw returns, $C R(-2,2)$

\begin{tabular}{clllc} 
& All firms & nonSOEs & SOEs & $\begin{array}{c}\text { nonSOE } \\
\text { minus SOE }\end{array}$ \\
\hline All provinces & $3.86^{* *}$ & $3.55^{*}$ & $4.01^{* *}$ & $-0.46^{* *}$ \\
Low-Marketization provinces & 0.98 & -3.00 & $4.30^{*}$ & $-7.30^{* * *}$ \\
High-Marketization provinces & $4.46^{* *}$ & $4.38^{*}$ & $4.50^{* *}$ & -0.13 \\
High- minus low-Marketization provinces & $3.49^{* * *}$ & $7.38^{* * *}$ & 0.20 &
\end{tabular}


Table III

Summary Statistics for Main Variables

Variable definitions and descriptions are provided in Appendix I.

\begin{tabular}{|c|c|c|c|c|c|c|}
\hline Samples & \multicolumn{2}{|c|}{ All firms } & \multicolumn{2}{|c|}{ nonSOEs } & \multicolumn{2}{|c|}{ SOEs } \\
\hline \multirow[t]{2}{*}{$\mathrm{N}$} & \multicolumn{2}{|c|}{2,024} & \multicolumn{2}{|c|}{1,173} & \multicolumn{2}{|c|}{851} \\
\hline & Mean & Std. & Mean & Std. & Mean & Std. \\
\hline 3 -day cumulative return $C R(-1,1), \%$ & 2.54 & 3.43 & 2.41 & 3.25 & 2.71 & 3.67 \\
\hline 5 -day cumulative return $C R(-2,2), \%$ & 3.77 & 4.65 & 3.55 & 4.43 & 4.09 & 4.92 \\
\hline Entertainment and travel costs (ETC) & 1.46 & 1.98 & 1.75 & 2.18 & 1.06 & 1.58 \\
\hline Marketization & 9.15 & 2.07 & 9.56 & 2.00 & 8.59 & 2.05 \\
\hline Growth Potential $(Q)$ & 2.94 & 2.43 & 3.18 & 2.64 & 2.60 & 2.06 \\
\hline External Finance Dependence (EFD) & -0.59 & 2.95 & -0.44 & 2.71 & -0.79 & 3.25 \\
\hline Total Factor Productivity (TFP) & 2.84 & 5.49 & 3.02 & 5.49 & 2.60 & 5.49 \\
\hline GDP Growth, \% & 11.75 & 1.88 & 11.56 & 1.75 & 12.02 & 2.02 \\
\hline $\log (G D P$ per capita $)$ & 10.59 & 0.45 & 10.63 & 0.41 & 10.52 & 0.49 \\
\hline Education Spending/GDP, \% & 2.69 & 1.16 & 2.52 & 1.10 & 2.92 & 1.21 \\
\hline Firm Size (log of Total Assets) & 21.67 & 1.31 & 21.24 & 1.06 & 22.26 & 1.40 \\
\hline Leverage (Liabilities/Total Assets) & 0.46 & 0.62 & 0.40 & 0.76 & 0.55 & 0.31 \\
\hline $\begin{array}{l}\text { Research and Development } \\
\text { (R\&D/sales) }\end{array}$ & 0.02 & 0.03 & 0.02 & 0.03 & 0.01 & 0.02 \\
\hline
\end{tabular}




\section{Table IV}

\section{Regression Analyses of Firm-level Cumulative Returns}

Regressions explain 3-day (Panel A) and 5-day (Panel B) cumulative returns, relative to industry fixed effects. Explanatory variables include the market reform index (Marketization), Entertainment and Travel Costs (ETC), and Total Factor Productivity, provincial GDP Growth, Log(per capita GDP), Education Spending/GDP, and firm-level controls (Firm Size, Leverage, and $R \& D$ ). Regressions also include interactions of Marketization with External Finance Dependence (industry fixed effects subsume External Finance Dependence main effects), Growth Potential (industry fixed effects subsume Growth Potential main effects), and ETC and Total Factor Productivity. Appendix I presents detailed definitions of all the variables. P-values are in parentheses. Significance at $10 \%, 5 \%$ and $1 \%$ levels indicated by $*$, $* *$, and $* * *$, respectively.

\begin{tabular}{|c|c|c|c|c|}
\hline \multicolumn{5}{|c|}{ Panel A: Explained variable is 3-day cumulative raw return $C R(-1,1)$} \\
\hline \multirow[t]{2}{*}{ Subsamples } & \multicolumn{2}{|c|}{ nonSOEs } & \multicolumn{2}{|c|}{ SOEs } \\
\hline & (1) & (2) & (3) & (4) \\
\hline Marketization & $\begin{array}{l}0.181 * * * \\
(0.00)\end{array}$ & $\begin{array}{r}0.047 \\
(0.58)\end{array}$ & $\begin{array}{l}-0.169^{*} \\
(0.09)\end{array}$ & $\begin{array}{l}-0.135 \\
(0.26)\end{array}$ \\
\hline$\times$ Growth Potential & & $\begin{array}{l}0.037 * * * \\
(0.00)\end{array}$ & & $\begin{array}{r}0.007 \\
(0.60)\end{array}$ \\
\hline$\times$ External Finance Dependence & & $\begin{array}{l}0.019 * * * \\
(0.00)\end{array}$ & & $\begin{array}{l}-0.011 \\
(0.34)\end{array}$ \\
\hline$\times$ Total Factor Productivity & & $\begin{array}{l}0.029 * * \\
(0.02)\end{array}$ & & $\begin{array}{l}-0.027 * \\
(0.08)\end{array}$ \\
\hline$\times E T C$ & & $\begin{array}{l}0.029 * * \\
(0.03)\end{array}$ & & $\begin{array}{l}-0.040 * \\
(0.05)\end{array}$ \\
\hline Total Factor Productivity & $\begin{array}{l}0.040^{* *} \\
(0.03)\end{array}$ & $\begin{array}{r}0.030 \\
(0.12)\end{array}$ & $\begin{array}{r}0.021 \\
(0.60)\end{array}$ & $\begin{array}{r}0.030 \\
(0.45)\end{array}$ \\
\hline ETC & $\begin{array}{l}-0.111^{* * *} \\
(0.00)\end{array}$ & $\begin{array}{l}-0.136^{* * *} \\
(0.00)\end{array}$ & $\begin{array}{r}0.044 \\
(0.40)\end{array}$ & $\begin{array}{l}0.099 * * \\
(0.04)\end{array}$ \\
\hline GDP Growth & $\begin{array}{l}0.208 * * * \\
(0.00)\end{array}$ & $\begin{array}{l}0.213 * * * \\
(0.00)\end{array}$ & $\begin{array}{l}-0.044 \\
(0.35)\end{array}$ & $\begin{array}{l}-0.041 \\
(0.41)\end{array}$ \\
\hline $\log (G D P$ per capita $)$ & $\begin{array}{l}0.208 * \\
(0.06)\end{array}$ & $\begin{array}{r}0.223 \\
(0.29)\end{array}$ & $\begin{array}{l}-0.073 \\
(0.72)\end{array}$ & $\begin{array}{l}-0.097 \\
(0.63)\end{array}$ \\
\hline Education Spending/GDP & $\begin{array}{l}0.238 * * * \\
(0.00)\end{array}$ & $\begin{array}{l}0.227^{*} \\
(0.06)\end{array}$ & $\begin{array}{l}-0.194 \\
(0.239)\end{array}$ & $\begin{array}{l}-0.166 \\
(0.31)\end{array}$ \\
\hline $\begin{array}{l}\text { P-value of Marketization and } \\
\text { its cross-terms joint F-test }\end{array}$ & & 0.04 & & 0.06 \\
\hline Controls \& Industry fixed-effects & Yes & Yes & Yes & Yes \\
\hline Bidirectional clustering by & Prov, Ind & Prov, Ind & Prov, Ind & Prov, Ind \\
\hline Observations & 1,173 & 1,173 & 851 & 851 \\
\hline Adjusted R-squared & 0.057 & 0.062 & 0.075 & 0.078 \\
\hline
\end{tabular}


Panel B: Explained variable is 5-day cumulative raw return $C R(-2,2)$

\begin{tabular}{|c|c|c|c|c|}
\hline \multirow[t]{2}{*}{ Subsamples } & \multicolumn{2}{|c|}{ nonSOEs } & \multicolumn{2}{|c|}{ SOEs } \\
\hline & (1) & (2) & (3) & (4) \\
\hline Marketization & $\begin{array}{l}0.266^{* *} \\
(0.02)\end{array}$ & $\begin{array}{r}0.128 \\
(0.35)\end{array}$ & $\begin{array}{l}-0.138 \\
(0.17)\end{array}$ & $\begin{array}{l}-0.155 \\
(0.21)\end{array}$ \\
\hline$\times$ Growth Potential & & $\begin{array}{l}0.029 * * * \\
(0.00)\end{array}$ & & $\begin{array}{l}0.034 * * \\
(0.02)\end{array}$ \\
\hline$\times$ External Finance Dependence & & $\begin{array}{l}0.035^{* * *} \\
(0.00)\end{array}$ & & $\begin{array}{l}-0.016^{* *} \\
(0.02)\end{array}$ \\
\hline$\times$ Total Factor Productivity & & $\begin{array}{l}0.026^{*} \\
(0.05)\end{array}$ & & $\begin{array}{l}-0.023 \\
(0.23)\end{array}$ \\
\hline$\times E T C$ & & $\begin{array}{l}0.059 * * * \\
(0.00)\end{array}$ & & $\begin{array}{l}-0.062 * * \\
(0.03)\end{array}$ \\
\hline Total Factor Productivity & $\begin{array}{l}0.071 * * * \\
(0.00)\end{array}$ & $\begin{array}{l}0.060 * * * \\
(0.00)\end{array}$ & $\begin{array}{r}0.085 \\
(0.21)\end{array}$ & $\begin{array}{r}0.092 \\
(0.15)\end{array}$ \\
\hline ETC & $\begin{array}{l}-0.199 * * * \\
(0.00)\end{array}$ & $\begin{array}{l}-0.249 * * * \\
(0000)\end{array}$ & $\begin{array}{r}0.076 \\
(0.17)\end{array}$ & $\begin{array}{l}0.158 * * \\
(0.02)\end{array}$ \\
\hline GDP Growth & $\begin{array}{l}0.287^{* * * *} \\
(0.00)\end{array}$ & $\begin{array}{l}0.284^{* *} \\
(0.01)\end{array}$ & $\begin{array}{l}-0.098 \\
(0.24)\end{array}$ & $\begin{array}{l}-0.089 \\
(0.32)\end{array}$ \\
\hline $\log (G D P$ per capita $)$ & $\begin{array}{r}0.172 \\
(0.50)\end{array}$ & $\begin{array}{r}0.223 \\
(0.50)\end{array}$ & $\begin{array}{l}-0.453^{* *} \\
(0.034\end{array}$ & $\begin{array}{l}-0.499 * * \\
(0.02)\end{array}$ \\
\hline Education Spending/GDP & $\begin{array}{l}0.375^{* *} \\
(0.05)\end{array}$ & $\begin{array}{l}0.354^{*} \\
(0.09)\end{array}$ & $\begin{array}{l}-0.176 \\
(0.41)\end{array}$ & $\begin{array}{l}-0.139 \\
(0.51)\end{array}$ \\
\hline $\begin{array}{l}\text { P-value of Marketization and } \\
\text { its cross-terms joint F-test }\end{array}$ & & 0.04 & & 0.03 \\
\hline Controls \& Industry fixed-effects & Yes & Yes & Yes & Yes \\
\hline Bidirectional clustering by & Prov, Ind & Prov, Ind & Prov, Ind & Prov, Ind \\
\hline Observations & 1,173 & 1,173 & 851 & 851 \\
\hline Adjusted R-squared & 0.099 & 0.105 & 0.090 & 0.093 \\
\hline
\end{tabular}


Appendix I

Variable Descriptions

\begin{tabular}{|c|c|}
\hline Variables & Descriptions \\
\hline$C R(-1,1)$ & $\begin{array}{l}\text { Three-trading-day cumulative stock return around the initiation of the } \\
\text { Eight-Point Policy on December 4, 2102, in percent. }\end{array}$ \\
\hline$C R(-2,2)$ & $\begin{array}{l}\text { Five-trading-day cumulative stock return around the December 4, } 2012 \\
\text { initiation of the Eight-Point Policy, in percent. }\end{array}$ \\
\hline ETC & Entertainment and travel costs as percent of sales in 2011 . \\
\hline SOES & $\begin{array}{l}\text { Indicator variable set to one if the firm is ultimately controlled by the } \\
\text { state or state organs and to zero otherwise, using a } 30 \% \text { "weakest link in } \\
\text { the control chain" rule as per the guidelines by China Stock Market and } \\
\text { Accounting Research (CSMAR) and the China Securities Regulatory } \\
\text { Commission (CSRC). }\end{array}$ \\
\hline Marketization & $\begin{array}{l}\text { A summary index measuring progress in implementing market reforms } \\
\text { for each of China's province-level jurisdictions (provinces, province- } \\
\text { level cities, and autonomous regions). A higher index means more } \\
\text { complete market reforms. Source: Fan et al. (2011). }\end{array}$ \\
\hline Growth Potential & Industry-average market value over book value of equity. \\
\hline $\begin{array}{l}\text { External Finance } \\
\text { Dependence (EFD) }\end{array}$ & $\begin{array}{l}\text { Industry-average of capital expenditures less cash flow from operations, } \\
\text { all divided by capital expenditures. }\end{array}$ \\
\hline $\begin{array}{l}\text { Total Factor Productivity } \\
\text { (TFP) }\end{array}$ & $\begin{array}{l}\text { Total factor productivity, estimated for each firm using the methodology } \\
\text { developed by Levinsohn and Petrin (2003). }\end{array}$ \\
\hline GDP Growth, \% & Province real GDP growth, averaged over 2009 to 2011. \\
\hline $\log (G D P$ per capita $)$ & Log of province real GDP per capita, averaged over 2009 to 2011. \\
\hline $\begin{array}{l}\text { Education } \\
\text { Spending/GDP, \% }\end{array}$ & Province education expenditures over GDP, averaged over 2009 to 2011. \\
\hline Firm Size Log(total assets) & The logarithm of firm total assets. \\
\hline $\begin{array}{l}\text { Leverage Liabilities/total } \\
\text { assets }\end{array}$ & Firm total liabilities over total assets. \\
\hline $\begin{array}{l}\text { Research and Development } \\
\text { (R\&D/sales) }\end{array}$ & $\begin{array}{l}\text { Firm research and development expenses over total sales, set to zero for } \\
\text { firms not reporting research and development spending. }\end{array}$ \\
\hline
\end{tabular}

